\title{
Dietary supplementation with free methionine or methionine dipeptide mitigates intestinal oxidative stress induced by Eimeria spp. challenge in broiler chickens
}

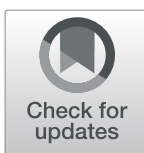

Angélica de Souza Khatlab ${ }^{1 *}$, Ana Paula Del Vesco ${ }^{2}$, Adhemar Rodrigues de Oliveira Neto $^{3}$, Roberta Pereira Miranda Fernandes ${ }^{4}$ and Eliane Gasparino ${ }^{1 *}$

\begin{abstract}
Background: This study evaluated the effects of Eimeria spp. challenge and dietary supplementation with free methionine or methionine dipeptide on animal performance; expression of genes associated with the immune system, antioxidant system, and amino acid transport in the jejunum; and redox status of the jejunum of broiler chickens.

Methods: A randomized, $2 \times 3$ factorial design was used, in which Eimeria spp. challenge was the first factor (Eimeria-challenged, EC, or unchallenged, UC, broilers) and methionine supplementation was the second factor (non-supplemented, NS; free DL-methionine, DL-Met; and methionine dipeptide, DL-methionyl-DL-methionine, DLMMet). At 14 days of age, chickens were inoculated orally with sporulated oocysts of Eimeria acervulina, Eimeria praecox, Eimeria maxima, and Eimeria mitis. Birds were killed by cervical dislocation $144 \mathrm{~h}$ post-inoculation (PI), and the jejunum was collected for biochemical and molecular analyses.

Results: EC broilers had a 13\% lower feed intake (FI), 37\% lower body weight gain (BWG), and 39\% higher feed conversion ratio (FCR) than UC broilers. Chickens fed the DL-Met diet had higher BWG (about 12\% higher) and better FCR (about 12\% lower) than chickens fed the NS diet. EC chickens had lower relative weight of the bursa of Fabricius (51.8\%) and higher relative weights of the spleen and whole intestine (53.6\% and $26.3 \%$, respectively) than UC chickens. Eimeria spp. challenge led to an increase in the levels of oxidative substances, such as nitrite and thiobarbituric acid reactive substances (TBARS), in the jejunum of chickens $144 \mathrm{~h} \mathrm{PI}$. Among UC chickens, those fed the DL-Met diet had higher total antioxidant capacity (TAC) and lower catalase (CAT) and superoxide dismutase (SOD) activities. EC chickens that received the NS diet had higher carbonylated protein content (CP). This result was associated with their lower TAC and catalase activity. The lower TAC in EC chickens might have been due to reduced expression of catalase (CAT) and superoxide dismutase 1 (SOD1) genes. Chickens fed the DL-Met and DLMMet diets had lower nitrite content. Eimeria spp. challenge suppressed neutral amino acid transporter $1\left(B^{0} A T 1\right)$, peptide transporter 1 (PEPT1), toll-like receptor 5 (TLR5), interleukin 2 (IL2), and occludin (OCLN) gene expression and enhanced cationic amino acid transporter 1 (CAT-1) and interferon gamma (IFNG) gene expression. The highest PEPT1 expression level was observed in broilers fed the DL-MMet diet, and the lowest TLR5 expression level was found in broilers fed the NS diet.

(Continued on next page)
\end{abstract}

\footnotetext{
* Correspondence: angelicakhatlabuem@gmail.com;

gasparinoeliane@gmail.com

1'Animal Science Department, State University of Maringá, Colombo Avenue,

5790, Jardim Universitário, Maringá, Paraná 87020-900, Brazil

Full list of author information is available at the end of the article
}

(c) The Author(s). 2019 Open Access This article is distributed under the terms of the Creative Commons Attribution 4.0 International License (http://creativecommons.org/licenses/by/4.0/), which permits unrestricted use, distribution, and reproduction in any medium, provided you give appropriate credit to the original author(s) and the source, provide a link to the Creative Commons license, and indicate if changes were made. The Creative Commons Public Domain Dedication waiver (http://creativecommons.org/publicdomain/zero/1.0/) applies to the data made available in this article, unless otherwise stated. 
(Continued from previous page)

Conclusion: Our results show for the first time that supplementation with methionine as free amino acid or dipeptide helps protect the intestinal cells of broilers under Eimeria spp. challenge from the oxidative damage induced by free radicals, mainly through modulation of the antioxidant system.

Keywords: Antioxidant, Coccidiosis, Gut, INFG, PEPT1,

\section{Background}

Coccidiosis, an intestinal infection caused by several species of coccidian protozoa of the genus Eimeria [1], can disturb metabolic and physiological homeostasis in broilers. During the infection, the immune [1] and antioxidant systems are activated [2], and alterations in nutrient digestion and absorption occur [3-5]. Several studies reported that animals with coccidiosis show changes in intestinal morphology [6,7], alterations in the expression of genes encoding digestive enzymes and transport proteins in the small intestine $[5,8]$, increased formation of reactive oxygen species (ROS) and reactive nitrogen species (RNS) [9], alterations in antioxidant enzyme activities $[2,10]$, and reduced concentrations of non-enzymatic antioxidants [11]. These changes are associated with poor animal performance, low efficiency, and increased mortality, causing global economic losses every year [12]. Although various anticoccidial drugs are available, they are not able to completely eliminate the disease. Alternative products have been tested for their immune stimulating, anti-inflammatory, and antioxidant properties [13]. Many antioxidants are used as supplements in poultry diets. Methionine, the first-limiting amino acid in corn and soybean meal broiler diets, has been highlighted as an important nutrient for the immune system [14] and antioxidant defense system [15]. Because of the crucial roles of methionine in physiological processes, $D L$-methionine, $L$-methionine, and methionine hydroxy analog (MHA) have been used for dietary supplementation. Methionine dipeptide has also been used as a dietary supplement $[16,17]$.

Because it is a small molecule, methionine dipeptide is absorbed mainly by peptide transporter 1 (PepT 1), present in the enterocyte membranes, whereas free amino acids are absorbed by specifics transporters [18]. Some studies have shown differences in the absorption efficiencies of dipeptides and free amino acids [17, 19]. Small peptides may be faster absorbed, as PepT 1 has a higher $V_{\max }$ than the transport systems used by free amino acids [20]. In addition, competition for the same transporter could reduce the absorption efficiency of specific amino acids [21]. Another advantage of dipeptides over free amino acids is that their absorption is less affected by intestinal mucosal lesions [22]. In previous studies, we showed the antioxidant effects of supplementation with MHA or $D L$-methionine in heat stress-exposed broilers $[23,24]$. In this study, we hypothesize that methionine supplementation can help alleviate the negative effects of Eimeria spp. challenge, and we test whether there are differences between the effects of free methionine supplementation and methionine dipeptide supplementation. In the case of diseases associated with reduced intestinal absorption, the administration of di- or tripeptides could be a protective factor against protein malnutrition [21]. Despite the importance of small peptides to animal health, few studies have investigated dipeptide supplementation. To the best of our knowledge, this is the first study reporting the biochemical and molecular effects of methionine dipeptide supplementation in broilers challenged with Eimeria spp.

\section{Methods}

This study was approved by the Ethics Committee on Animal Use (CEUA No. 4000170615) of the State University of Maringá, Brazil.

\section{Animals and experimental design}

A total of 384 one-day-old unvaccinated Cobb 500 male broilers were used. The chicks were raised in a temperature-controlled environment at an initial temperature of $33^{\circ} \mathrm{C}$ with $24 \mathrm{~h}$ of artificial light per day. The temperature was gradually reduced according to bird age, as recommended by Cobb 500 management guidelines. Birds were housed in raised floor cages of $1.0 \mathrm{~m}^{2}$ (8 chickens per cage). Chicks were raised conventionally up to 10 days of age, after which they were reared following a completely randomized, $2 \times 3$ factorial design with eight replicates of eight birds per treatment. The first factor was Eimeria spp. challenge (Eimeria-challenged, EC, or unchallenged, UC, broilers) and the second factor was methionine supplementation (non-supplemented, NS; free $D L$-methionine, $D L$-Met; and $D L$-methionyl-DL-methionine, DL-MMet). Before birds were submitted to the respective treatments, they were fasted for $6 \mathrm{~h}$ and weighed.

At 14 days of age, one group of chicks from each diet treatment $(n=64)$ were inoculated orally with $1 \mathrm{~mL}$ of a solution containing sporulated oocysts of Eimeria spp. (EC group; $2 \times 10^{4}$ Eimeria acervulina, $2 \times 10^{4}$ Eimeria praecox, $1.6 \times 10^{4}$ Eimeria maxima, and $4 \times 10^{4}$ Eimeria mitis). UC chickens received orally $1 \mathrm{~mL}$ of saline solution. Each group was housed separately to avoid cross-infection. All birds 
were killed by cervical dislocation $144 \mathrm{~h}$ post-inoculation (PI) at 20 days of age. Birds had free access to water and feed throughout the experimental period. Experimental diets containing corn and soybean meal were formulated according to Rostagno et al. [25], and no anticoccidial drugs were added to the diets. Diet composition is shown in Table 1, and analyzed and calculated nutrient compositions are shown in Table 2.

\section{Coprological analysis for coccidiosis diagnosis and histological analysis of the duodenum and jejunum} A pool of fresh excreta samples was randomly withdrawn from the cages of EC animals, and another pool was withdrawn from the cages of UC animals, $144 \mathrm{~h}$ PI. Coprological analysis was performed for the qualitative detection (presence or absence) of oocysts in excreta, as described by Gordon and Whitlock [26] with modifications. Approximately $2 \mathrm{~g}$ of feces was dissolved in $15 \mathrm{~mL}$ of distilled water and centrifuged at $2500 \mathrm{r} / \mathrm{min}$ for 2 min. The supernatant was discarded, and the pellet was dissolved in $10 \mathrm{~mL}$ of sucrose solution (density 1.18). This mixture was centrifuged again at $2500 \mathrm{r} / \mathrm{min}$ for 2 $\mathrm{min}$. Then, the material was placed on a histological slide for oocyst detection. An Olympus BX50 Optical P1 microscope coupled to an Olympus PMC 35 B camera (40× objective lens) was used for visual analysis.

Duodenum and jejunum samples were collected immediately after slaughter (144 h PI) for histological analysis.

Table 1 Composition of experimental diets, \%, as is, fed to 10-20 days old broilers

\begin{tabular}{llll}
\hline Ingredient, kg & NS $^{\mathrm{a}}$ & DL-Met & DL-MMet \\
\hline Corn (7.8\%) & 54.89 & 54.89 & 54.89 \\
Soybean meal (46\%) & 37.30 & 37.30 & 37.30 \\
Soybean oil & 3.80 & 3.80 & 3.80 \\
L-Lysine HCl (78\%) & 0.16 & 0.16 & 0.16 \\
L-Threonine (98.5\%) & 0.04 & 0.04 & 0.04 \\
DL-Methionyl-DL-Methionine (95\%, dipeptide) & - & - & 0.29 \\
DL-Methionine (99\%) & - & 0.28 & - \\
Dicalcium phosphate (20\%) & 1.53 & 1.53 & 1.53 \\
Limestone (38\%) & 1.16 & 1.16 & 1.16 \\
Salt & 0.45 & 0.45 & 0.45 \\
Vitamin-mineral premix ${ }^{b}$ & 0.40 & 0.40 & 0.40 \\
Inert filler & 0.30 & 0.02 & 0.01 \\
Total & 100.00 & 100.00 & 100.00
\end{tabular}

${ }^{a} N S$ Non-supplemented diet (control diet), DL-Met diet supplemented with DLmethionine $99 \%$, DL-MMet diet supplemented with

$D L$-methionyl-DL-methionine $95 \%$

${ }^{\mathrm{b}}$ The diets supplied the following compounds (per $\mathrm{kg}$ ): retinyl acetate, 3.44 $\mathrm{mg}$; cholecalciferol, $50 \mu \mathrm{g}$; DL-a-tocopherol, $15 \mathrm{mg}$; thiamine, $1.63 \mathrm{mg}$; riboflavin, $4.9 \mathrm{mg}$; pyridoxine, $3.26 \mathrm{mg}$; cyanocobalamin, $12 \mu \mathrm{g}$; $D$-pantothenic acid, $9.8 \mathrm{mg}$; D-biotin, $0.1 \mathrm{mg}$; menadione, $2.4 \mathrm{mg}$; folic acid, $0.82 \mathrm{mg}$; niacinamide, $35 \mathrm{mg}$; selenium, $0.2 \mathrm{mg}$; iron, $35 \mathrm{mg}$; copper, $8 \mathrm{mg}$; manganese, $60 \mathrm{mg}$; zinc, $50 \mathrm{mg}$; iodine, $1 \mathrm{mg}$; and butylated hydroxy toluene, $80 \mathrm{mg}$
Table 2 Calculated and analyzed nutrient composition, $\mathrm{g} / \mathrm{kg}$, as is, of experimental diets fed to 10-20 days old broilers

\begin{tabular}{llll}
\hline Nutrients & $N^{a}$ & DL-Met & DL-MMet \\
\hline Analyzed composition ${ }^{\mathrm{b}}, \mathrm{g} / \mathrm{kg}$ & & & \\
$\quad$ Crude protein & 217 & 220 & 216 \\
Lysine & $12.87(100)^{\mathrm{c}}$ & $12.78(100)$ & $12.59(100)$ \\
Methionine & $3.05(24)$ & $5.78(45)$ & $5.84(46)$ \\
Methionine + Cystine & $6.53(51)$ & $9.10(71)$ & $9.17(73)$ \\
Threonine & $8.54(66)$ & $8.73(68)$ & $8.41(67)$ \\
Tryptophan & $2.81(22)$ & $2.85(22)$ & $2.79(22)$ \\
Valine & $10.39(81)$ & $10.56(83)$ & $10.12(80)$ \\
Isoleucine & $9.56(74)$ & $9.75(76)$ & $9.27(74)$ \\
Arginine & $14.52(113)$ & $14.89(117)$ & $14.34(114)$ \\
Calculated composition & & & \\
AME ${ }^{d}, \mathrm{kcal} / \mathrm{kg}$ & 3053 & 3052 & 3052 \\
Calcium, g/kg & 8.76 & 8.76 & 8.76 \\
Available phosphorus, g/kg & 4.50 & 4.50 & 4.50 \\
Sodium, g/kg & 2.00 & 2.00 & 2.00
\end{tabular}

${ }^{a} N S$ Non-supplemented diet (control diet), DL-Met diet supplemented with DLmethionine 99\%, DL-MMet diet supplemented with

DL-methionyl-DL-methionine $95 \%$

${ }^{\mathrm{b}}$ Feeds were formulated using the total amino acid contents of corn and soybean meal determined by near infrared reflectance spectroscopy. The total amino acid and other nutrient values are shown as gram per kilogram and not as a percentage of the diets. Total amino acid compositions were analytically determined by Evonik Industries (Hanau, Germany) using wet chemistry (highperformance liquid chromatography)

'Values in parentheses indicate the amino acid-to-lysine ratios (ideal protein concept)

${ }^{\mathrm{d}} A M E$ Apparent metabolizable energy

Samples were cut longitudinally, carefully washed with cold sterile physiological saline, and fixed in Bouin's solution for 6 h. After fixation, samples were dehydrated through a graded ethanol series, diaphanized in xylol, and embedded in paraffin. Semi-serial histological sections of $3 \mu \mathrm{m}$ thickness were obtained. Samples were stained with hematoxylin-eosin, and histological images were captured using the Olympus BX 50 P1 Optical microscope coupled to the Olympus PMC 35 B camera ( $4 \times$ and $40 \times$ objective lenses).

\section{Animal performance and relative weight of organs}

Animals were weighed at days 14 and 20 after a 6-hour fasting period, during which they had free access to water. For performance evaluation, each cage (eight birds per cage, $n=8$ ) was considered an experimental unit. Feed intake (FI) was calculated as the amount of feed offered at the beginning of the experimental period (day 14) minus the feed residue at the end of the experimental period (day 20). Body weight gain (BWG) was calculated by the difference between the mean initial weight (day 14) and mean final weight (day 20). Feed conversion ratio (FCR) was calculated as the ratio of FI to BWG.

For analysis of relative organ weight, each bird was considered an experimental unit $(n=8)$, birds were selected 
according on the body weight average of each replicate. At 20 days of age (144 $\mathrm{h} \mathrm{PI}$ ), chickens were fasted for $6 \mathrm{~h}$ and then killed by cervical dislocation. The liver, whole intestine, spleen, and bursa of Fabricius were collected and weighed. The relative weight of the organs was calculated using the equation organ weight/body weight $\times 100$.

\section{Analysis of the redox state of the jejunum}

Six birds from each treatment, chosen on the basis of the average body weight of each replicate group, were killed by cervical dislocation $144 \mathrm{~h}$ PI. The jejunum was collected, washed with cold sterile physiological saline, frozen in liquid nitrogen, and stored at $-80^{\circ} \mathrm{C}$ until analysis.

\section{Sample preparation}

Nitrite $\left(\mathrm{NO}_{2}{ }^{-}\right)$content, catalase (CAT) activity, superoxide dismutase (SOD) activity, and thiobarbituric acid reactive substances (TBARS) content were determined. Briefly, $100 \mathrm{mg}$ of jejunum was added to $1000 \mu \mathrm{L}$ of 0.1 $\mathrm{mol} / \mathrm{L}$ potassium phosphate buffer, $\mathrm{pH}$ 7.4. The solution was homogenized using a Van Potter homogenizer until complete dissociation and centrifuged at $10,000 \times g$ for 10 min at $4{ }^{\circ} \mathrm{C}$. The supernatant was collected in a clean eppendorf tube and used as a sample.

For analysis of carbonylated proteins (CP), $200 \mathrm{mg}$ of jejunum was added to $1000 \mu \mathrm{L}$ of $0.05 \mathrm{~mol} / \mathrm{L}$ phosphate buffer with $0.001 \mathrm{~mol} / \mathrm{L}$ ethylenediaminetetraacetic acid (EDTA), pH 6.7. The solution was homogenized using a Van Potter homogenizer until complete dissociation. Then, the homogenate was centrifuged at $10,000 \times g$ for 10 min at $4{ }^{\circ} \mathrm{C}$. The supernatant was collected in a clean eppendorf tube and used as a sample.

\section{Analysis of CAT and SOD activities}

CAT activity was assessed by evaluating the ability of the enzyme to convert hydrogen peroxide $\left(\mathrm{H}_{2} \mathrm{O}_{2}\right)$ to water and molecular oxygen. Twenty microliters of supernatant was added to $980 \mu \mathrm{L}$ of the reaction mixture $(1$ $\mathrm{mol} / \mathrm{L}$ Tris buffer containing $0.005 \mathrm{~mol} / \mathrm{L}$ EDTA, pH 8.0, and $\mathrm{H}_{2} \mathrm{O}_{2}$ ). Enzyme activity was monitored using an Evolution $^{\text {tw }} 300$ UV-VIS spectrophotometer (Thermo Fisher Scientific $\left.\mathrm{c}^{\mathrm{m}}\right)$, and readings were performed at 240 $\mathrm{nm}$ for $60 \mathrm{~s}$. CAT activity was expressed as the amount of $\mathrm{H}_{2} \mathrm{O}_{2}$ consumed per minute per milligram of protein $(\varepsilon=33.33 \mathrm{~mol} / \mathrm{L} \mathrm{cm})$ [27].

SOD activity was measured as the ability of the enzyme to inhibit the autoxidation of pyrogallol, which generates superoxide anions $\left(\mathrm{O}_{2}^{-} \bullet\right)$. SOD competes with the detection system for $\mathrm{O}_{2}^{-}$. The absorbance increase was measured at $420 \mathrm{~nm}$ for $180 \mathrm{~s}$ using a microplate reader (VersaMax ${ }^{\mathrm{Tn}}$, Molecular Devices). The jejunum supernatant was added to $0.2 \mathrm{~mol} / \mathrm{L}$ Tris- $\mathrm{HCl}$ buffer containing $0.002 \mathrm{~mol} / \mathrm{L}$ EDTA, $\mathrm{pH} 8.2$, and $0.015 \mathrm{~mol} / \mathrm{L}$ pyrogallol. The analysis was performed in duplicate at room temperature. A unit of SOD (U) was defined as the amount of enzyme required to inhibit the autoxidation rate of pyrogallol by $50 \%$. SOD activity was expressed as $\mathrm{U} / \mathrm{mg}$ of protein [28].

\section{Determination of biomarkers of oxidative stress and total antioxidant capacity (TAC)}

Analysis of $\mathrm{NO}_{2}{ }^{-}$, one of the two stable and non-volatile primary products of nitric oxide degradation, was performed to assess the formation of nitric oxide during infection, as it is a potential inducer of oxidative stress [29]. $\mathrm{NO}_{2}{ }^{-}$determination was based on the diazotization reaction described by Griess [30]. Briefly, $50 \mu \mathrm{L}$ of a sulfanilamide solution ( $1 \%$ sulfanilamide diluted in $5 \%$ phosphoric acid; Sigma-Aldrich) was added to microplate wells containing $25 \mu \mathrm{L}$ of the sample. The microplate was incubated for $10 \mathrm{~min}$ at room temperature in the dark. Then, a solution of $0.1 \% \mathrm{~N}-(1$-naphthyl) ethylenediamine dihydrochloride (NED) (Sigma-Aldrich) in milli-Q water was added to the reaction, and samples were read at $540 \mathrm{~nm}$ using a microplate reader (Versa$\operatorname{Max}^{\mathrm{TM}}$, Molecular Devices). The concentration of nitrite in the jejunum was calculated from a standard curve prepared using sodium nitrite $\left(\mathrm{NaNO}_{2}\right)$. The results were expressed as $\mu \mathrm{mol}$ nitrite/mg of protein.

Lipid peroxidation was assessed as described by Buege and Aust [31], on the basis of the ability of thiobarbituric acid to bind to oxidized lipids. Samples were read at $535 \mathrm{~nm}$ using the Evolution ${ }^{\text {Tm }} 300$ UV-VIS spectrophotometer (Thermo Fisher Scientific ${ }^{\mathrm{m} \mathrm{N}}$ ). TBARS content was determined using a molar extinction coefficient of $1.56 \times 10^{5} \mathrm{~mol} / \mathrm{L} \mathrm{cm}$, according to the Beer-Lambert law. Results were expressed as nmol TBARS/mg of protein.

For analysis of protein oxidation, we measured the formation of carbonyl derivatives using the reagent 2,4-dinitrophenylhydrazine (DNPH, Sigma-Aldrich), as described by Levine et al. [32]. Readings were performed at $370 \mathrm{~nm}$ on the Evolution ${ }^{\mathrm{nx}} 300$ UV-VIS spectrophotometer (Thermo Fisher Scientific $\left.{ }^{\mathrm{Tm}}\right)$. Carbonylated protein concentration was determined using the BeerLambert equation, $A=C \times b \times \varepsilon$, where $A$ is the absorbance of the sample minus that of the control, $C$ is the concentration of carbonylated proteins, $b$ is the optical path length, and $\varepsilon$ is the molar extinction coefficient $(22,000 \mathrm{~mol} / \mathrm{L} \mathrm{cm})$. Results were expressed as nmol carbonylated protein $/ \mathrm{mg}$ of protein.

Total antioxidant capacity (TAC) was measured by the 2,2-diphenyl-1-picrylhydrazyl (DPPH, Sigma-Aldrich) radical scavenging assay, according to the method described by Brand-Williams et al. [33], with modifications. Briefly, $100 \mathrm{mg}$ of jejunum was added to $1000 \mu \mathrm{L}$ of methanol. The solution was homogenized using a Van Potter homogenizer and centrifuged at $10,000 \times g$ for 10 $\min$ at $4^{\circ} \mathrm{C}$. Then, $1850 \mu \mathrm{L}$ of a $6 \times 10^{-5} \mathrm{~mol} / \mathrm{L} \mathrm{DPPH}$ 
solution was added to an eppendorf tube containing $150 \mu \mathrm{L}$ of the supernatant obtained from the samples. The solution was kept in the dark for $30 \mathrm{~min}$. Subsequently, samples were read at $515 \mathrm{~nm}$ using the Evolu$\operatorname{tion}^{\mathrm{Tm}} 300$ UV-VIS spectrophotometer (Thermo Fisher Scientific $\left.{ }^{\mathrm{rx}}\right)$. The antioxidant capacity of each sample was calculated as follows: \% Antioxidant activity $=[1-(a b-$ sorbance of the sample/absorbance of DPPH) $\times 100$.

The Bradford method [34] was used to determine total protein content and correct $\mathrm{NO}_{2}^{-}, \mathrm{CAT}, \mathrm{SOD}$, carbonylated protein, and TBARS results.

\section{Gene expression}

The jejunum of six birds from each treatment, selected on the basis of the average body weight of each replicate group, was collected $144 \mathrm{~h}$ PI, washed with cold sterile saline, and added to an eppendorf tube containing $1 \mathrm{~mL}$ of TRIzol ${ }^{\mathrm{m}}$ (Invitrogen, Carlsbad CA, USA). Samples were stored at $-80^{\circ} \mathrm{C}$ until total RNA extraction.

Total RNA was extracted according to the manufacturer's recommendations and quantified spectrophotometrically at $260 \mathrm{~nm}$ on a NanoDrop 2000c spectrophotometer (Thermo Fisher Scientific $\left.\mathrm{c}^{\mathrm{rw}}\right)$. RNA integrity was assessed on a $1 \%$ agarose gel stained with $\mathrm{SYBR}^{\mathrm{m}}$ Safe DNA Gel Stain (Invitrogen, Carlsbad CA, USA) and visualized under ultraviolet light using a photodocumentation system for electrophoresis gel (L-PIX TOUCH, Loccus Biotechnology). To eliminate genomic DNA contamination, we treated $1 \mu \mathrm{g}$ of total RNA with DNase I, Amplification Grade (Invitrogen, Carlsbad CA, USA), according to the manufacturer's instructions. Subsequently, complementary DNA (cDNA) synthesis was performed using the SuperScript ${ }^{\text {tw }}$ III First-Strand Synthesis SuperMix kit (Invitrogen Corporation, Brazil) according to the manufacturer's instructions. cDNA concentration was determined at $260 \mathrm{~nm}$ using the NanoDrop ${ }^{\text {Tw }} 2000 \mathrm{c}^{\text {spectro- }}$ photometer (Thermo FisherScientificTM). cDNA samples were stored at $-20^{\circ} \mathrm{C}$ until amplification.

RT-qPCR was performed using $5 \mu \mathrm{L}$ of cDNA diluted to 40 or $80 \mathrm{ng} / \mu \mathrm{L}, 0.5 \mu \mathrm{L}$ or $1 \mu \mathrm{L}$ of $10 \mu \mathrm{mol}$ forward primer and $10 \mu \mathrm{mol}$ reverse primer (final concentrations of $200 \mathrm{nmol}$ and $400 \mathrm{nmol}$, respectively), $12.5 \mu \mathrm{L}$ of SYBR ${ }^{\mathrm{mm}}$ Green PCR Master Mix (Applied Biosystems ${ }^{\mathrm{Tm}}$, USA), and UltraPure ${ }^{\mathrm{Tm}}$ DEPC-treated water (Invitrogen ${ }^{\mathrm{mm}}$, Carlsbad CA, USA) to complete the volume to $25 \mu \mathrm{L}$. RT-qPCR reactions were performed on a StepOne ${ }^{\mathrm{Tn}}$ real-time PCR system version 2.3 (Applied Biosystems $\mathrm{s}^{\mathrm{Tm}}$ ), and the thermal cycle for all genes was set to $95^{\circ} \mathrm{C}$ for $10 \mathrm{~min}$ followed by 40 cycles of denaturation at $95^{\circ} \mathrm{C}$ for $15 \mathrm{~s}$ and annealing and extension at $60^{\circ} \mathrm{C}$ for $1 \mathrm{~min}$, ending with heating from $65^{\circ} \mathrm{C}$ to $95^{\circ} \mathrm{C}$ for melting curve analysis.

Primers specific to the genes that code for superoxide dismutase 1 (SOD1), catalase (CAT), peptide transporter 1 (PEPT1), neutral and cationic amino acid transporter 1 $\left(y^{+} L A T-1\right)$, neutral amino acid transporter $1\left(B^{O} A T 1\right)$, cationic amino acid transporter 1 (CAT-1), toll-like receptor 2 (TLR2), toll-like receptor 5 (TLR5), interleukin 1 beta (IL1B), interleukin 2 (IL2), interferon gamma (IFNG), lipopolysaccharide-induced tumor necrosis factor (TNF)-alpha factor (LITAF), claudin-1 (CLDN1), occludin (OCLN), and inducible nitric oxide synthase (iNOS) were designed on the basis of gene sequences deposited in the National Center for Biotechnology Information (NCBI, http://www. ncbi.nlm.nih.gov) database (Table 3) using the Integrated DNA Technologies system (http://www.idtdna.com). The $\beta$-actin gene $(A C T B)$ was used as an endogenous control. All analyses were performed in duplicate, and results were expressed as arbitrary units, AU. The $2^{-\Delta \mathrm{CT}}$ method was used to evaluate gene expression [35].

\section{Statistical analysis}

The Shapiro-Wilk test was applied to verify the normality of data distribution. Data were analyzed by two-way ANOVA, which considers the main effects (Eimeria spp. challenge and methionine supplementation) and the interaction between the factors. Means were compared by the Tukey test $(P<0.05)$ using SAS 2002 version 9.00 (SAS Inst. Inc., Cary, NC).

\section{Results}

The absence of oocysts in the excreta of UC broilers validates their use as controls (Fig. 1a). The infection caused by Eimeria spp. in EC broilers was confirmed by the presence of oocysts in the excreta samples (Fig. 1b), histological alterations in the intestinal mucosal (Fig. 1c), and the presence of Eimeria spp. structures in duodenal enterocytes (Fig. 1d) and in jejunal enterocytes and lamina propria (Fig. 1f). The jejunal villi of UC broilers were normal, confirming the absence of infection and the integrity of the intestinal epithelium (Fig. 1e).

\section{Animal performance and relative weight of organs}

Eimeria spp. challenge and methionine supplementation showed no interaction effect on performance parameters (Table 4). However, FI, BWG, and FCR values of EC chickens were respectively $13 \%$ lower, $37 \%$ lower, and $39 \%$ higher $(P<0.0001)$ than those of UC chickens. Methionine supplementation had a significant effect on BWG $(P=0.0038)$ and FCR $(P=0.0190)$, as chickens fed the DL-Met diet had higher BWG (about 12\% higher) and better FCR (about 12\% lower) than chickens fed the NS diet. No differences were observed between chickens fed DL-Met and DL-MMet diets.

The effects of Eimeria spp. challenge and methionine supplementation on the relative weight of organs are presented in Fig. 2a and Fig. 2b, respectively. Eimeria spp. challenge had significant effects on the relative weight of the bursa of Fabricius $(P<0.0001)$, spleen $(P<$ $0.0001)$, and whole intestine $(P<0.0001)$ (Fig. 2a). EC 
Table 3 Primer sequences used for RT-qPCR

\begin{tabular}{|c|c|c|c|}
\hline Gene & Primer sequences $\left(5^{\prime} \rightarrow 3^{\prime}\right)$ & Amplicon, bp ${ }^{a}$ & Accession No. \\
\hline \multirow[t]{2}{*}{$\overline{S O D 1^{b}}$} & F: AGATGGCAGTGGGAAATGAG & 110 & NM_205064.1 \\
\hline & R: ACTCAAGACAGCAGAGTAGTAATG & & \\
\hline \multirow[t]{2}{*}{ CAT } & F: GAGGAACCCTCAGACTCATTTG & 117 & NM_001031215.2 \\
\hline & R: CCATCAGGAATACCACGATCAC & & \\
\hline \multirow[t]{2}{*}{ PEPT1 } & F: CCCCTGAGGAGGATCACTGTT & 66 & KF366603.1 \\
\hline & R: CAAAAGAGCAGCAGCAACGA & & \\
\hline \multirow[t]{2}{*}{$y^{+} L A T-1$} & F: TGTTGGAGCCAGAGAAGGA & 118 & XM_418326.6 \\
\hline & R: CACAAGGAGATAAAGCAAAGTC & & \\
\hline \multirow[t]{2}{*}{$B^{0} A T 1$} & F: TCTATTGAAGATTCGGGCAC & 153 & XM_419056.6 \\
\hline & R: AATGGTAAGCACAAGGTATGG & & \\
\hline \multirow[t]{2}{*}{$C A T-1$} & F: CGTGGCATCTCTGCTCATC & 134 & NM_001145490.1 \\
\hline & R: CTCCATCCCAACCTACATACTTA & & \\
\hline \multirow[t]{2}{*}{$T L R 2$} & F: ACTGCCTGCAACGGTCAT & 75 & NM_204278.1 \\
\hline & R: CATCAGCTTCATTGTTGGTTTCTGT & & \\
\hline \multirow[t]{2}{*}{ TLR5 } & F: ACACGGCAATAGTAGCAACACATAT & 91 & XM_025148815.1 \\
\hline & R: ACACCTGGAACTTGGAAAAGAACAT & & \\
\hline \multirow[t]{2}{*}{$\operatorname{ILIB}$} & F: GTCAACATCGCCACCTACAA & 90 & XM_015297469.1 \\
\hline & R: CGGTACATACGAGATGGAAACC & & \\
\hline \multirow[t]{2}{*}{ IL2 } & F: CCTCAAGAGTCTTACGGGTCTA & 104 & GU119890.1 \\
\hline & R: AGTTGGTCAGTTCATGGAGAAA & & \\
\hline \multirow[t]{2}{*}{ IFNG } & F: TGAGGTGATGTTTACCGAGTIT & 94 & NM_205149.1 \\
\hline & R: GCTTAGAGCTGAGCAGGTATG & & \\
\hline \multirow[t]{2}{*}{ LITAF } & F: GAGCGTTGACTTGGCTGTC & 64 & NM_204267.1 \\
\hline & R: AAGCAACAACCAGCTATGCAC & & \\
\hline \multirow[t]{2}{*}{ CLDN1 } & F: ACTCCTGGGTCTGGTTGGT & 100 & AY750897.1 \\
\hline & R: GACAGCCATCCGCATCTTCT & & \\
\hline \multirow[t]{2}{*}{ OCLN } & F: ACGGCAGCACCTACCTCAA & 123 & D21837.1 \\
\hline & R: GGGCGAAGAAGCAGATGAG & & \\
\hline \multirow[t]{2}{*}{ iNOS } & F: TCCTGAGTTCTGTGCCTTTG & 92 & U46504.1 \\
\hline & R: GTTCATCTCCTTCACCCACTG & & \\
\hline \multirow[t]{2}{*}{$A C T B$} & F: GCCAACAGAGAGAAGATGAC & 130 & L08165.1 \\
\hline & R: CACCAGAGTCCATCACAATAC & & \\
\hline
\end{tabular}

${ }^{\mathrm{a}} b p$ Base pairs

${ }^{\mathrm{b}}$ SOD1 Superoxide dismutase 1 gene, CAT Catalase gene, PEPT1 Peptide transporter 1 gene, $y^{+}$LAT- 1 Neutral and cationic amino acid transporter 1 gene, $B^{0} A T 1$ System $B^{0}$ neutral amino acid transporter 1 gene, CAT-1 Cationic amino acid transporter 1 gene, TLR2 Toll-like receptor 2 gene, TLR5 Toll-like receptor 5 gene, IL1B Interleukin 1 beta gene, IL2 Interleukin 2 gene, IFNG Interferon gamma gene, LITAF Lipopolysaccharide-induced tumor necrosis factor-alpha factor gene, CLDN1 Claudin-1 gene, OCLN Occludin gene, iNOS Inducible nitric oxide synthase gene, $F$ Forward, $R$ Reverse

birds had lower relative weight of the bursa of Fabricius and higher relative weight of the spleen and whole intestine than UC birds (Fig. 2a). There was no effect of Eimeria spp. challenge on liver weight (Fig. 2a). Methionine supplementation had no effect on the relative weight of the organs $(P>0.05)$ (Fig. 2b).

\section{Redox state of the jejunum}

An interaction effect between Eimeria spp. challenge and methionine supplementation on TAC, $\mathrm{CP}$, and CAT and SOD activities in the jejunum of chickens was observed (Table 5). Within the UC group, there was no effect of diet on $\mathrm{CP}$; however, chickens fed the DL-Met diet had higher TAC and lower CAT and SOD activities. Regarding EC chickens, the highest level of carbonylated protein $(\mathrm{CP})$ was found in the jejunum of chickens fed the NS diet. This result was associated with lower TAC and CAT activity. EC chickens fed the $D L$-Met and $D L$-MMet diets had CP levels similar to those of UC chickens fed the same 

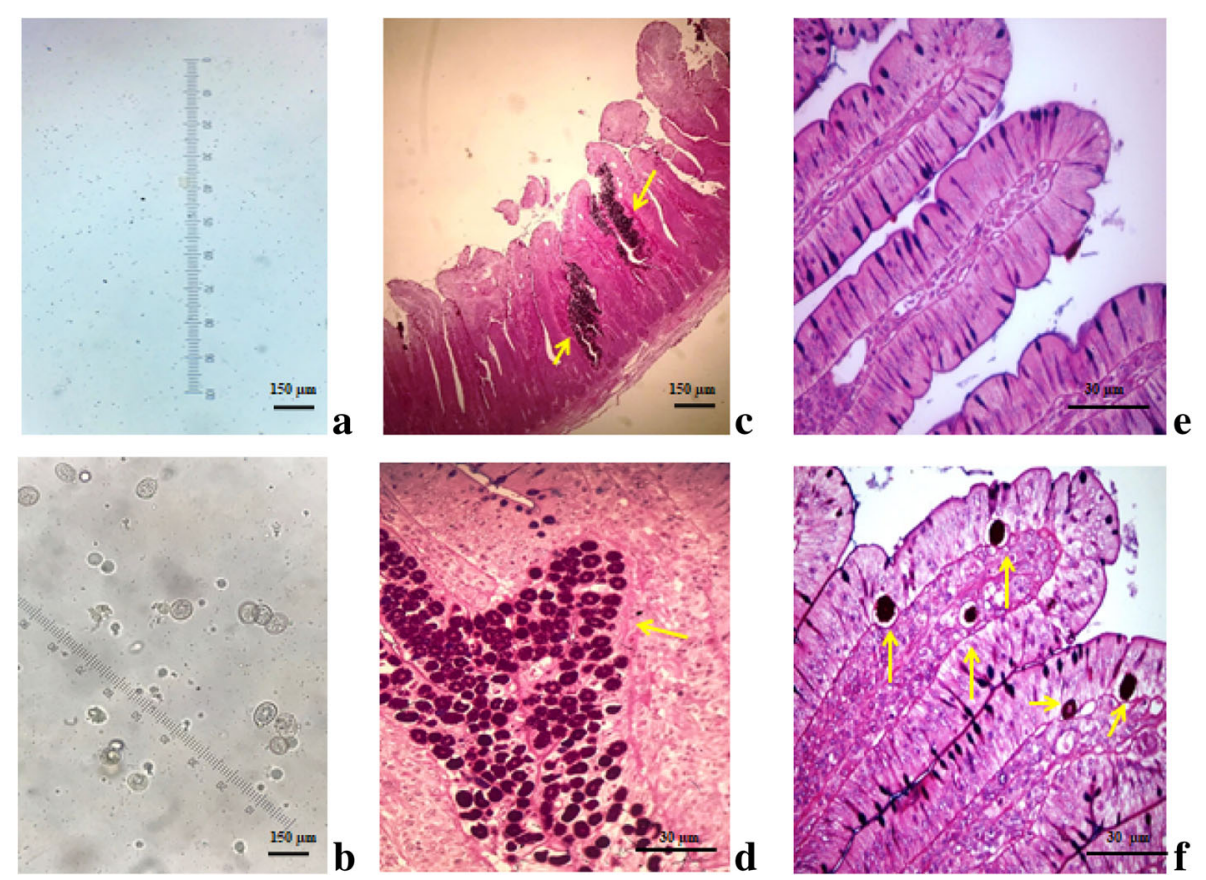

Fig. 1 Oocysts detection in the feces of unchallenged, UC $\mathbf{a}$ and Eimeria-challenged, EC $\mathbf{b}$ broiler chickens $144 \mathrm{~h}$ post-inoculation (PI). c, d Histological images of duodenal villi and $\mathbf{e}$, $\mathbf{f}$ jejunal villi in broiler chickens $144 \mathrm{~h} \mathrm{Pl}, 40 \times$ magnification. Note the presence of Eimeria structures (yellow arrows) in the duodenal and jejunal mucosa of EC broilers. e Intact jejunal villi in UC broilers. Hematoxylin-eosin staining. $\mathbf{a}$, b, c Scale bars represent $150 \mu \mathrm{m}$. d, e, f Scale bars represent $30 \mu \mathrm{m}$

diets, indicating the role of methionine as an antioxidant in the metabolism of EC chickens.

The lower TAC observed in EC chickens might also be associated with the reduced expression of $C A T(P<$ $0.0001)$ and SOD1 $(P=0.0036)$ genes (Fig. 3). There was no effect of methionine supplementation on the expression of these genes.

EC chickens had higher nitrite and TBARS contents than UC chickens. Birds fed the $D L$-Met and DL-MMet diets showed lower nitrite contents than birds fed the NS diet. There was no effect of methionine supplementation on TBARS content (Fig. 4).

\section{Expression of genes associated with intestinal function and integrity}

We investigated the effects of the treatments on the expression of genes related to the function and integrity of the intestinal tract. The expression of genes encoding $y^{+} L A T-1, B^{0} A T 1, C A T-1$, and PEPT1 in the jejunum of broilers $144 \mathrm{~h}$ PI is shown in Fig. 5a and Fig. 5b. Eimeria spp. challenge affected the expression of $B^{O} A T 1(P=$ $0.0001), C A T-1 \quad(P=0.0300)$, and PEPT1 $(P<0.0001)$ (Fig. 5a). EC chickens showed lower $B^{O} A T 1$ (0.1589 AU vs. $0.2166 \mathrm{AU})$ and PEPT1 (0.4644 AU vs. $2.5611 \mathrm{AU})$ and higher $C A T-1(0.0028 \mathrm{AU}$ vs. $0.0012 \mathrm{AU})$ gene expression than UC chickens. Eimeria spp. challenge had no significant effect on $y^{+} L A T-1$ expression $(P>0.05)$
(Fig. 5a). Methionine supplementation (Fig. 5b) influenced PEPT1 expression $(P=0.0467)$ : broilers fed the DL-MMet diet had higher expression levels of this gene. There was no effect of methionine supplementation on the expression of the genes $y^{+} L A T-1, C A T-1$, and $B^{O} A T 1$ $(P>0.05)$ (Fig. 5b).

Figure 6 shows the results of CLDN1 and OCLN gene expression. EC chickens had decreased expression of OCLN compared to UC chickens. There was no effect of Eimeria spp. challenge on CLDN1 expression $(P=$ $0.1825)$, and no effect of methionine supplementation on the expression of CLDN1 $(P=0.6416)$ and OCLN $(P=$ 0.1595).

\section{Expression of genes associated with immune responses}

The effects of Eimeria spp. challenge on the relative expression of TLR2, TLR5, IL1B, IL2, LITAF, and IFNG genes are shown in Fig. 7. Eimeria spp. challenge significantly reduced the expression of TLR5 $(P=0.0003)$ and IL2 $(P=0.0001)$ and significantly increased the expression of IFNG $(P=0.0001)$. However, no significant effect of Eimeria spp. challenge on the expression of TLR2, $I L 1 B$, and LITAF was observed $(P>0.05)$ (Fig. 7).

The effects of diet on the relative expression of TLR2, TLR5, IL1B, IL2, IFNG, and LITAF genes are presented in Fig. 8. Chickens fed the NS diet had lower expression of TLR5 than chickens fed the DL-MMet diet $(P=$ 
Table 4 Performance of broilers $144 \mathrm{~h}$ post-inoculation with Eimeria spp.

\begin{tabular}{|c|c|c|c|c|c|c|c|}
\hline & \multicolumn{2}{|l|}{$\mathrm{Fl}, \mathrm{kg}^{\mathrm{c}}$} & \multicolumn{2}{|c|}{$B W G, k g^{d}$} & \multicolumn{2}{|l|}{ FCR } \\
\hline & & Mean & SE & $\overline{\text { Mean }}$ & SE & $\overline{\text { Mean }}$ & SE \\
\hline \multirow[t]{3}{*}{$\overline{U C^{f}}$} & $N S^{h}$ & 0.470 & 0.011 & 0.295 & 0.009 & 1.593 & 0.016 \\
\hline & DL-Met' & 0.498 & 0.009 & 0.333 & 0.006 & 1.515 & 0.042 \\
\hline & DL-MMet & 0.493 & 0.015 & 0.315 & 0.015 & 1.568 & 0.115 \\
\hline \multirow[t]{3}{*}{$E C^{g}$} & NS & 0.428 & 0.006 & 0.183 & 0.009 & 2.378 & 0.108 \\
\hline & DL-Met & 0.420 & 0.009 & 0.213 & 0.003 & 1.987 & 0.047 \\
\hline & DL-MMet & 0.415 & 0.006 & 0.198 & 0.005 & 2.101 & 0.069 \\
\hline \multicolumn{8}{|l|}{ Main effects } \\
\hline \multirow[t]{2}{*}{ Challenge } & UC & $0.487^{\mathrm{a}}$ & 0.007 & $0.314^{a}$ & 0.007 & $1.558^{\mathrm{b}}$ & 0.038 \\
\hline & EC & $0.421^{b}$ & 0.004 & $0.198^{\mathrm{b}}$ & 0.005 & $2.155^{\mathrm{a}}$ & 0.064 \\
\hline \multirow[t]{3}{*}{ Diet } & NS & 0.449 & 0.010 & $0.239^{b}$ & 0.022 & $1.985^{\mathrm{a}}$ & 0.157 \\
\hline & DL-Met & 0.459 & 0.016 & $0.273^{\mathrm{a}}$ & 0.023 & $1.751^{\mathrm{b}}$ & 0.094 \\
\hline & DL-MMet & 0.454 & 0.016 & $0.256^{\mathrm{ab}}$ & 0.023 & $1.834^{\mathrm{ab}}$ & 0.118 \\
\hline \multicolumn{8}{|l|}{$P$-value } \\
\hline \multicolumn{2}{|l|}{ Challenge } & \multicolumn{2}{|c|}{$<0.0001$} & \multicolumn{2}{|c|}{$<0.0001$} & \multicolumn{2}{|c|}{$<0.0001$} \\
\hline \multicolumn{2}{|l|}{ Diet } & \multicolumn{2}{|c|}{0.6033} & \multicolumn{2}{|c|}{0.0038} & \multicolumn{2}{|c|}{0.0190} \\
\hline \multicolumn{2}{|c|}{ Challenge $\times$ Diet } & \multicolumn{2}{|c|}{0.1487} & \multicolumn{2}{|c|}{0.9062} & \multicolumn{2}{|c|}{0.1155} \\
\hline
\end{tabular}

${ }^{\mathrm{a}, \mathrm{b}}$ Means in the same column followed by different letters differ significantly by the Tukey test, $P<0.05$. Results are presented as mean \pm standard error, SE. Each cage was considered an experimental unit, $n=8$. No mortality was observed during the experimental period

${ }^{\mathrm{C}} \mathrm{Fl}$ Feed intake. Performance data were calculated taking into consideration a period of 6 days, that is, the period of $144 \mathrm{~h}$ post-inoculation, $\mathrm{PI}$ with Eimeria spp.

${ }^{d} B W G$ Body weight gain. Performance data were calculated taking into consideration a period of 6 days, that is, the period of $144 \mathrm{~h}$ post-inoculation, PI with Eimeria spp.

${ }^{\mathrm{e}} \mathrm{FCR}$ Feed conversion ratio. Performance data were calculated taking into consideration a period of 6 days, that is, the period of $144 \mathrm{~h}$ post-inoculation, PI with Eimeria spp.

${ }^{f}$ UC Unchallenged broilers

${ }^{g}$ EC Eimeria-challenged broilers

${ }^{\mathrm{h}} \mathrm{NS}$ non-supplemented diet

${ }^{i} D L-M e t$ diet supplemented with free methionine, $D L-$ methionine $99 \%$

${ }^{\mathrm{j}} D L-M M e t$ diet supplemented with methionine dipeptide,

$D L$-methionyl-DL-methionine $95 \%$

0.0255). There was no difference between the sources of methionine. No significant effect was observed on the expression of TLR2, IL1B, and LITAF $(P>0.05)$ (Fig. 8).

No effect of Eimeria spp. challenge or methionine supplementation was observed on the expression of the gene iNOS (Fig. 9) $(P>0.05)$.

\section{Discussion}

Previous studies showed that broilers challenged with Eimeria spp. have poor performance in part because of structural and functional changes that occur in the intestinal mucosa during the infection $[5,7,8]$. We observed that EC chickens had FI and BWG 13\% and 37\% lower than UC chickens, respectively. The decreased BWG in EC chickens was followed by an increase of 39\% in FCR. The reduced FI in EC chickens might be related, among other factors, to the increase in plasma cholecystokinin secretion, a potent inhibitor of feeding [36]. Low BWG may have been caused by several factors, such as low FI and low expression of the genes $B^{\circ} A T 1$ and PEPT1 in the jejunum. $B^{O} A T 1$ encodes the neutral amino acid transporter $\left(\mathrm{B}^{0} \mathrm{AT} 1\right)$, and PEPT1 encodes a protein responsible for the uptake of di- and tripeptides. Thus, a reduced expression of $B^{O} A T 1$ and PEPT1 genes could be associated with decreased absorption of amino acids and decreased protein synthesis.

PepT 1 is highly resilient to changes in the gut caused by intestinal damage $[18,21]$. We hypothesized that DL-MMet supplementation could exert a beneficial effect on animal metabolism during Eimeria spp. challenge. No interaction effect between Eimeria spp. challenge and methionine supplementation on the expression of PEPT1 was observed. However, there was a significant reduction in PEPT1 expression in the jejunum of EC broilers compared with that of UC broilers and a higher expression in animals fed the $D L$-Met and $D L$-MMet diets than in those fed the NS diet. The lower PEPT1 expression in EC birds might be due to lower nutrient intake, as they exhibited lower FI. Chen et al. [37] suggest that end products of protein digestion (small peptides and amino acids) may be involved in PEPT1 expression pathways. We suggest that methionine stimulates PEPT1 expression and that, because PepT 1 is a low-affinity, high-capacity transporter, increased expression of these gene could be related to higher nutrient absorption [18]. Furthermore, we found that chickens fed diets with methionine supplementation had higher BWG and better FCR than chickens fed the NS diet. Although studies indicate that, in some species, dipeptides are more readily absorbed, and thus more readily available, than free amino acids $[17,21,22]$ in this study we did not observe differences in the BWG of animals fed DL-Met or $D L$-MMet diets. This result may be related to the bioefficacy of methionine sources. Similar bioefficacy values were observed between chickens fed free methionine $(D L-\mathrm{M})$ and methionine dipepitde $(D L-\mathrm{MM})$ diets in a study by Silva et al. [38]. A thorough investigation on the nutritional and metabolic effects of dipeptide methionine supplementation for chickens is needed.

The effects of coccidiosis are not limited to poor animal performance. Several changes in the composition of organs and tissues were observed in animals infected with coccidia [39]. As the weight of lymphoid organs can be used as an indication of the body's ability to deliver lymphoid cells during immune responses [40], we evaluated the relative weight of the bursa of Fabricius and of the spleen. We observed that EC broilers showed lower relative weight of the bursa of Fabricius, as reported in other study [41], and higher relative weight of the spleen and whole intestine, which is also in 

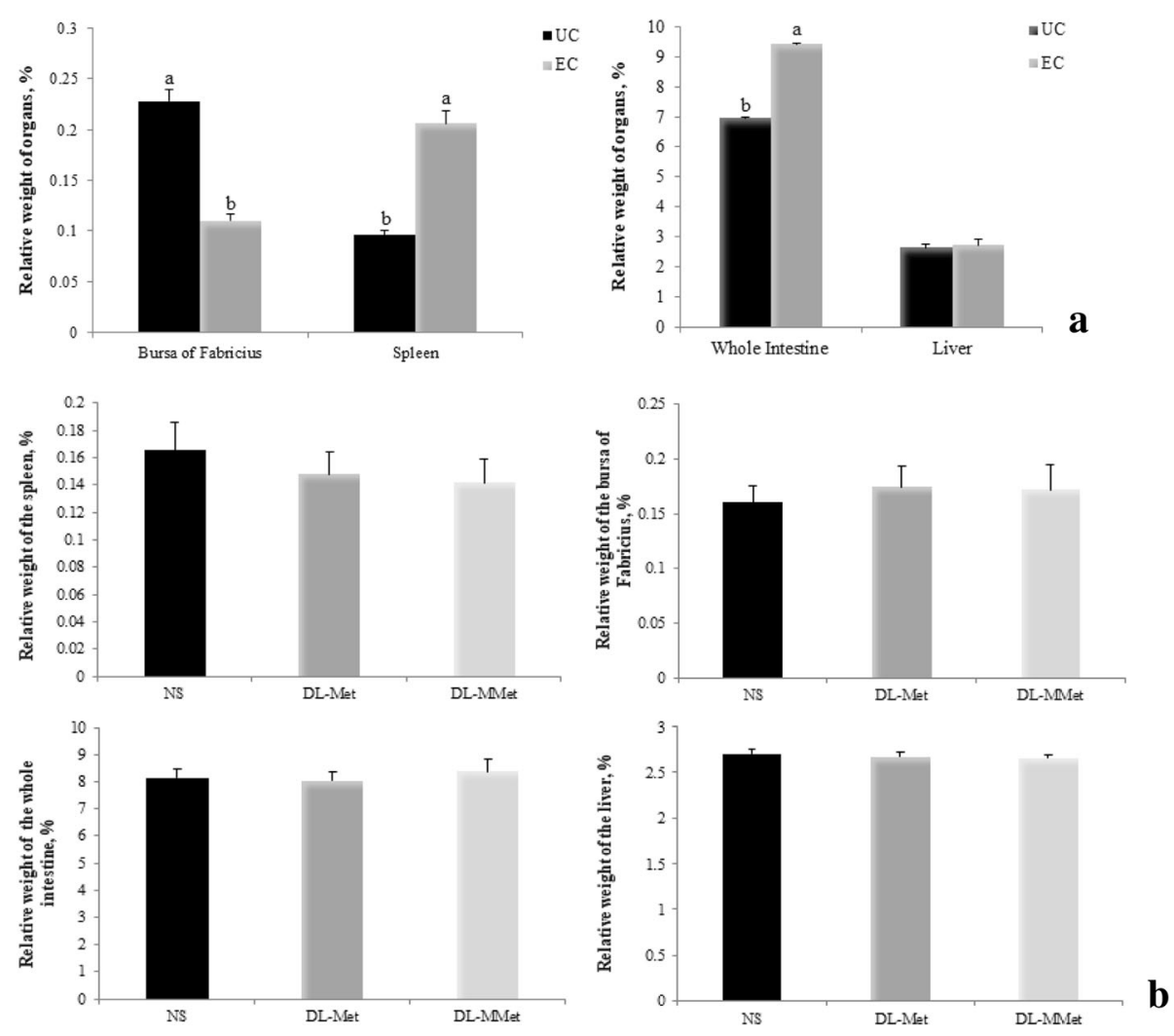

Fig. 2 Effects of Eimeria spp. challenge $\mathbf{a}$ and methionine supplementation $\mathbf{b}$ on the relative weight of organs of broilers. Results are presented as mean and standard error. ${ }^{a, b}$ Different letters represent significant differences between treatments by the Tukey test, $P<0.05$. UC = unchallenged broilers; EC = Eimeria-challenged broilers; NS = non-supplemented diet; DL-Met = diet supplemented with free methionine; $\mathrm{DL}-\mathrm{MMet}=$ diet supplemented with methionine dipeptide

Table 5 Carbonylated protein, CP, total antioxidant capacity, TAC, and antioxidant enzyme activities in the jejunum of broilers $144 \mathrm{~h}$ post-inoculation with Eimeria spp

\begin{tabular}{|c|c|c|c|c|c|c|c|c|c|}
\hline & & \multicolumn{2}{|l|}{$C P^{d}$} & \multicolumn{2}{|l|}{ TAC $^{e}$} & \multicolumn{2}{|c|}{ Catalase $^{f}$} & \multicolumn{2}{|l|}{ SOD $^{9}$} \\
\hline & & $\overline{\text { Mean }}$ & SE & $\overline{\text { Mean }}$ & SE & $\overline{\text { Mean }}$ & SE & $\overline{\text { Mean }}$ & SE \\
\hline \multirow[t]{3}{*}{$\overline{U C^{h}}$} & $N S^{j}$ & $1.05^{b c}$ & 0.11 & $64.36^{C}$ & 3.52 & $28.27^{\mathrm{a}}$ & 2.06 & $4.49^{\mathrm{ab}}$ & 0.09 \\
\hline & $D L-M e t^{k}$ & $1.04^{b c}$ & 0.17 & $81.89^{a}$ & 2.15 & $21.47^{\mathrm{bc}}$ & 1.42 & $3.82^{c}$ & 0.04 \\
\hline & DL-MMet' & $1.27^{\mathrm{ab}}$ & 0.16 & $71.39^{b c}$ & 1.69 & $27.78^{\mathrm{a}}$ & 1.28 & $3.69^{c}$ & 0.13 \\
\hline \multirow[t]{3}{*}{$E C^{i}$} & NS & $1.43^{\mathrm{a}}$ & 0.10 & $65.27^{c}$ & 2.10 & $19.62^{c}$ & 1.25 & $4.72^{\mathrm{a}}$ & 0.05 \\
\hline & DL-Met & $0.85^{c}$ & 0.15 & $67.45^{c}$ & 3.06 & $24.77^{\mathrm{ab}}$ & 1.94 & $4.32^{b}$ & 0.11 \\
\hline & DL-MMet & $0.90^{b c}$ & 0.07 & $78.32^{\mathrm{ab}}$ & 2.52 & $22.38^{\mathrm{bc}}$ & 0.49 & $3.59^{c}$ & 0.1 \\
\hline
\end{tabular}

P-value

Challenge $\times$ Diet

0.0200

0.0008

0.0012

0.0214

\footnotetext{
bird was considered an experimental unit, $n=6$

${ }^{d}$ Expressed as nmol of carbonyl groups/mg of protein

$\mathrm{TAC}=$ total antioxidant capacity, expressed as percentage, $\%$

${ }^{f}$ Catalase activity, expressed as the amount of hydrogen peroxide, $\mathrm{H}_{2} \mathrm{O}_{2}$ consumed per minute per milligram of protein

${ }^{9} \mathrm{SOD}=$ superoxide dismutase activity, expressed as SOD unit/mg of protein

${ }^{h} U C=$ unchallenged broilers

'EC = Eimeria-challenged broilers

${ }^{\mathrm{j}} \mathrm{NS}=$ non-supplemented diet

${ }^{k_{D L}-M e t}=$ diet supplemented with free methionine (DL-methionine $99 \%$ )

I $D L-M M e t=$ diet supplemented with methionine dipeptide (DL-methionyl-DL-methionine 95\%)
}

$\overline{a, b, c}$ Means in the same column followed by different letters differ significantly by the Tukey test, $P<0.05$. Results are presented as mean \pm standard error, SE. Each 

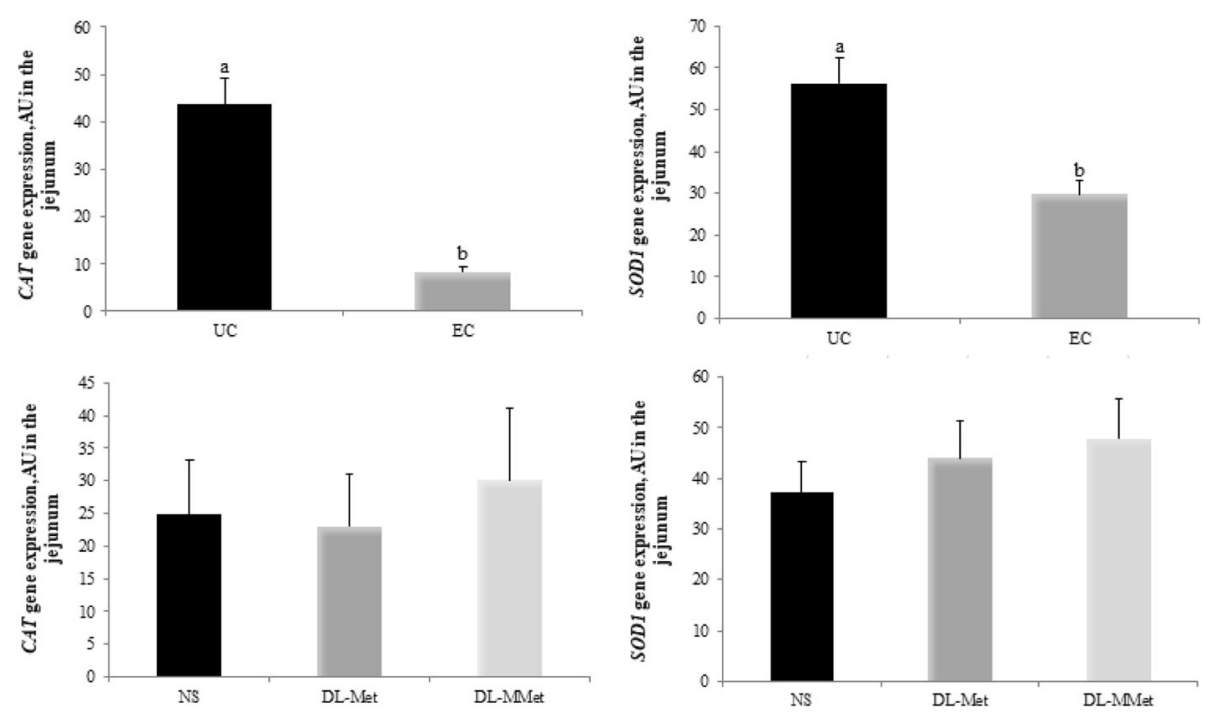

Fig. 3 Expression of catalase, CAT and superoxide dismutase 1, SOD1 genes in the jejunum of broiler chickens. Results are expressed as arbitrary units, $A U$, and are presented as mean and standard error. ${ }^{a, b}$ Different letters represent significant differences between treatments by the Tukey test, $P<0.05$. UC = unchallenged broilers; $E C=$ Eimeria-challenged broilers. NS = non-supplemented diet; $D L-$ Met $=$ diet supplemented with free methionine; $\mathrm{DL}-\mathrm{MMet}=$ diet supplemented with methionine dipeptide
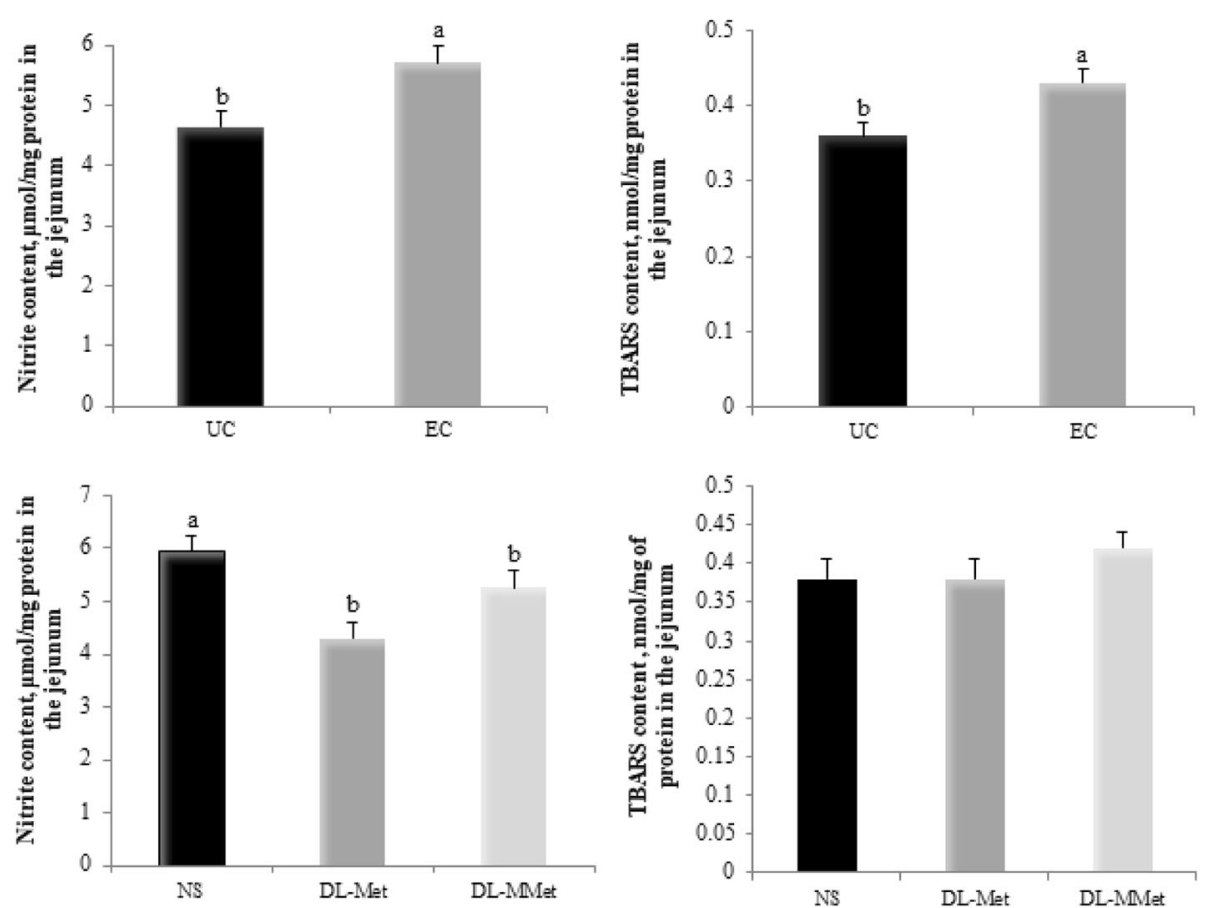

Fig. 4 Effect of Eimeria spp. challenge and methionine supplementation on nitrite, $\mathrm{NO}_{2}{ }^{-}$content and thiobarbituric acid reactive substances, TBARS content in the jejunum of broiler chickens $144 \mathrm{~h}$ post-inoculation. Results are presented as mean and standard error. ${ }^{\mathrm{a}, \mathrm{b}}$ Different letters represent significant differences by the Tukey test, $P<0.05$. UC $=$ unchallenged broilers; $E C=$ Eimeria-challenged broilers; NS $=$ non-supplemented diet; $D L-M e t=$ diet supplemented with free methionine; $D L-M M e t=$ diet supplemented with methionine dipeptide 

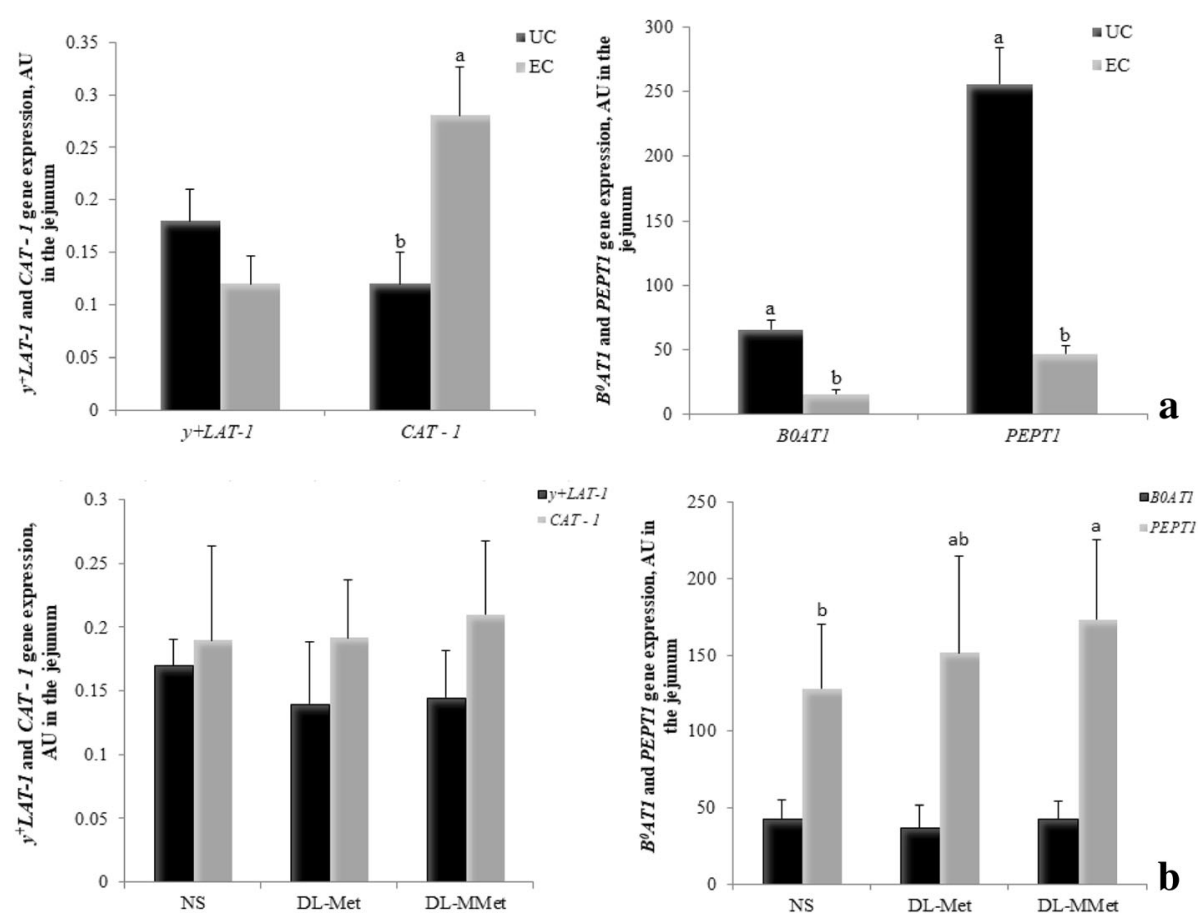

Fig. 5 Effect of Eimeria spp. challenge $\mathbf{a}$ and methionine supplementation $\mathbf{b}$ on the expression of genes encoding $y^{+} L A T-1, B^{0}$ AT1, CAT-1, and PEPT1 in the jejunum of broilers. Results are expressed as arbitrary units, $\mathrm{AU}$, and are presented as mean and standard error. ${ }^{\text {a,b }}$ Different letters represent significant differences between treatments by the Tukey test, $P<0.05$. UC $=$ unchallenged broilers; $E C=$ Eimeria-challenged broilers. NS $=$ nonsupplemented diet; DL-Met $=$ diet supplemented with free methionine; $D L-M M e t=$ diet supplemented with methionine dipeptide. $y^{+} L A T-1=$ neutral and cationic amino acid transporter 1 gene. CAT- $1=$ cationic amino acid transporter 1 gene; $B^{0}$ AT 1 = system $B^{0}$ neutral amino acid transporter 1 gene; PEPT1 = peptide transporter 1 gene
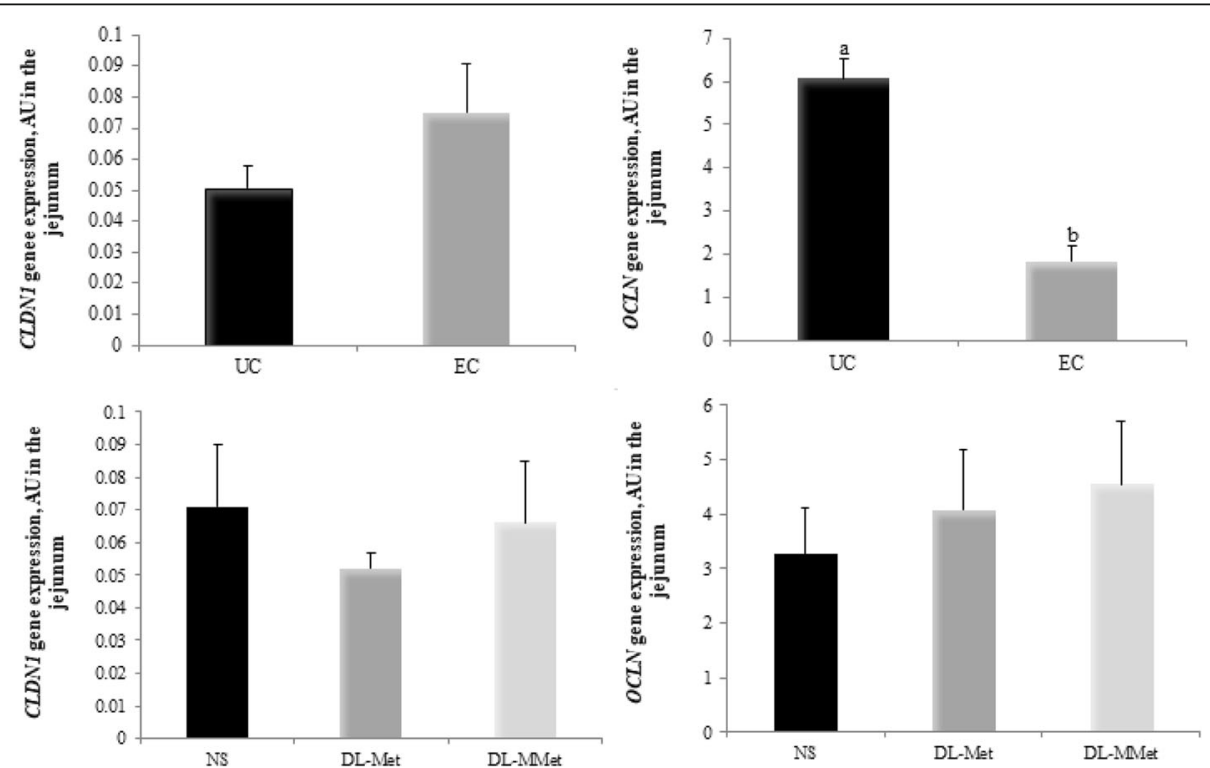

Fig. 6 Effect of Eimeria spp. challenge and methionine supplementation on the expression of genes encoding claudin-1, CLDN1 and occludin, OCLN in the jejunum of broiler chickens $144 \mathrm{~h}$ post-inoculation. Results are expressed as arbitrary units, $\mathrm{AU}$, and are presented as mean and standard error. ${ }^{a, b}$ Different letters represent significant differences between treatments by the Tukey test, $P<0.05$. NS $=$ non-supplemented diet; $D L-M e t=$ diet supplemented with free methionine; $D L-M M e t=$ diet supplemented with methionine dipeptide 

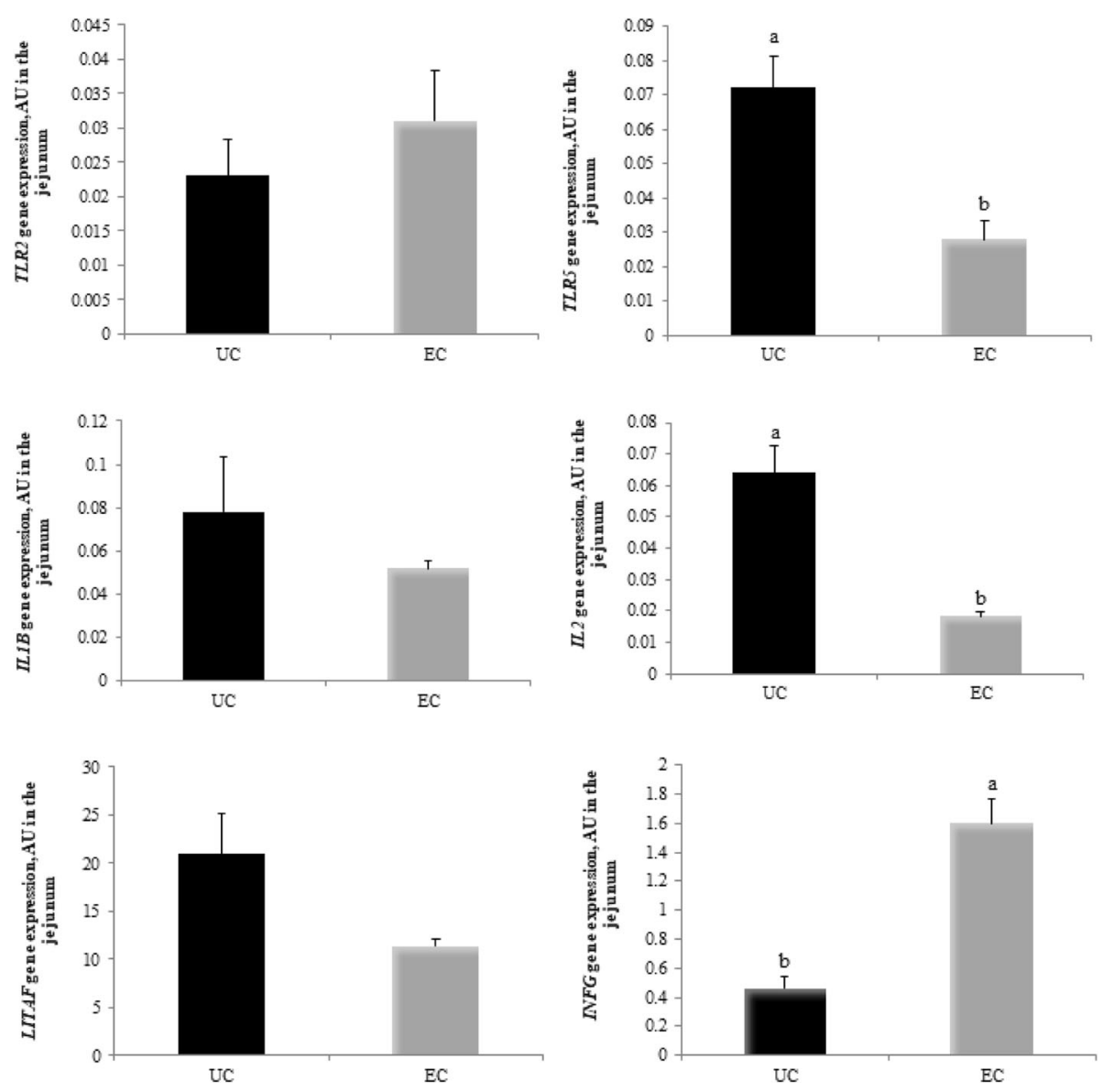

Fig. 7 Expression of genes associated with the immune system in the jejunum of broilers $144 \mathrm{~h}$ post-inoculation with Eimeria spp. Results are expressed as arbitrary units, $\mathrm{AU}$, and are presented as mean and standard error. ${ }^{a, b}$ Different letters represent significant differences between treatments by the Tukey test, $P<0.05$. UC = unchallenged broilers; $E C=$ Eimeria-challenged broilers. TLR2 = toll-like receptor 2 gene; $T L R 5=$ toll-like receptor 5 gene; $I L I B=$ interleukin 1 beta gene; IL2 = interleukin 2 gene; LITAF = lipopolysaccharide-induced tumor necrosis factor-alpha factor gene; IFNG = interferon gamma gene

agreement with the results of previous works $[42,43]$. A low relative weight of the bursa of Fabricius can be attributed to organ atrophy caused by lymphocyte depletion or to micronecrosis and cell migration [44]. Increased relative weight of the spleen can represent the body's attempt to meet the requirements of the humoral and cellular immunity [42]. Increased intestine weight might be associated with edema formation, thickening of the mucosa [1], hypertrophy, or mucosal hyperplasia as a result of cell proliferation to replace damaged epithelial cells [45].

During the course of the infection, immunological reactions generate a microenvironment that is incompatible with the survival of pathogens and confer protective immunity against Eimeria spp. reinfection [1]. The immune system of a parasitized animal detects and responds rapidly to infection through innate immune receptors [46], such as the transmembrane TLRs, which play an important role in immune responses against
Eimeria spp. [47]. TLRs are expressed by most immune cells [48] as well as by intestinal epithelial cells (IECs) and lamina propria cells [49]. Recognition of pathogenassociated molecular patterns (PAMPs) triggers TLR signaling via myeloid differentiation primary response 88 (MyD88) and TIR-domain-containing adapter-inducing interferon- $\beta$ (TRIF), inducing the expression of IL-12, IFNs, and TNF [50], which are important effector molecules in innate and adaptive immunity against pathogenic microorganisms [50, 51]. EC chickens showed lower TLR5 expression than UC chickens. This result might be related to the time of sample collection ( $144 \mathrm{~h}$ PI). According to Netea et al. [52], the innate immune system is activated within minutes of invasion by the protozoan and remains active mainly during the first days of infection. On the other hand, chickens fed the NS diet had the lowest TLR5 expression levels. Zhang et al. [50] suggested that high expression of TLR5 can be caused by TLR 5 recognition of flagellin in the normal 

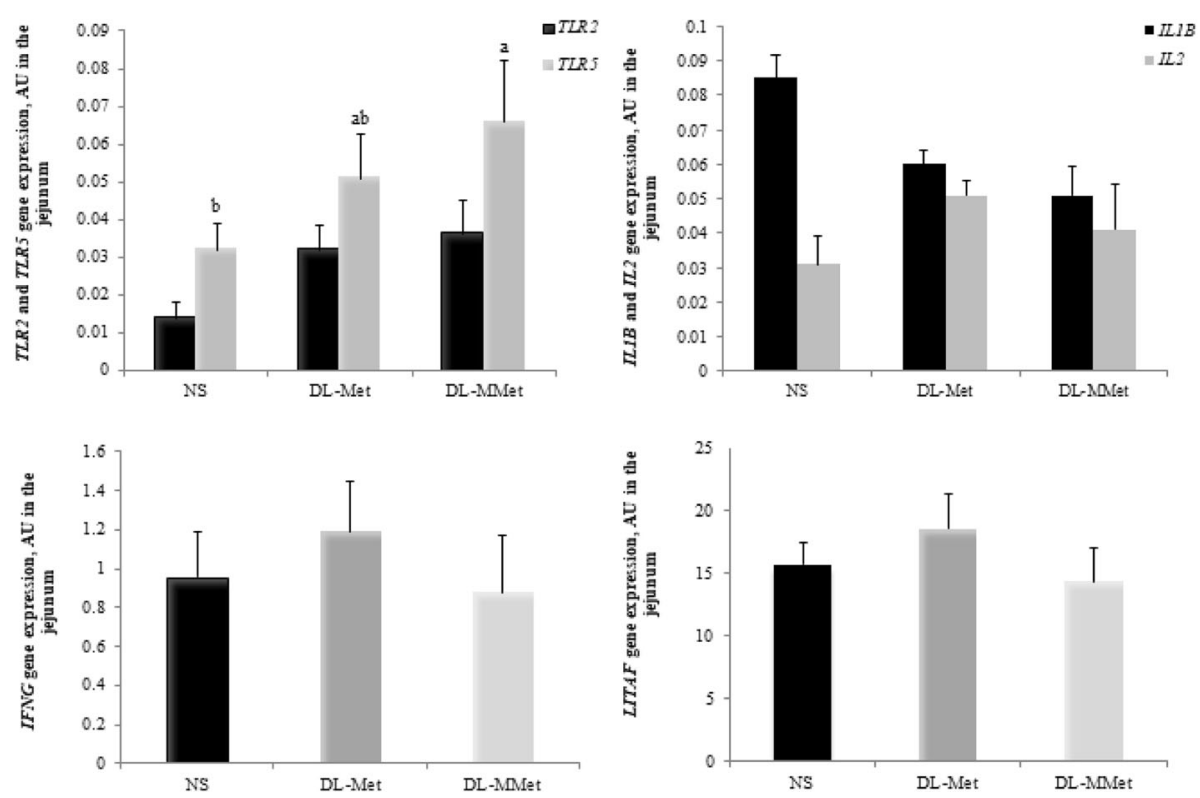

Fig. 8 Effect of methionine supplementation on the expression of the toll-like receptor 2 gene, TLR2, toll-like receptor 5 gene, TLR5, interleukin 1 beta gene, ILIB, interleukin 2 gene, IL2, interferon gamma gene, IFNG, and lipopolysaccharide-induced tumor necrosis factor-alpha factor, LITAF gene in the jejunum of broiler chickens. Results are expressed as arbitrary units, $A U$, and are presented as mean and standard error. ${ }^{a, b}$ Different letters represent significant differences between treatments by the Tukey test, $P<0.05$. NS = non-supplemented diet; $D L-M e t=$ diet supplemented with free methionine; $D L-M M e t=$ diet supplemented with methionine dipeptide

intestinal flora of animals. According to Tang et al. [53], methionine influences the intestinal microflora by stimulating the growth of beneficial bacteria. Our results indicate that methionine deficiency negatively affects immune response activation, possibly because it causes changes in the intestinal flora normal of chickens. EC chickens showed lower IL2 expression than UC chickens. According to Kaiser et al. [54], low IL2 levels can result in slower inflammatory responses in the intestine, allowing invasion of intestinal epithelial cells by Eimeria spp. and progression of the parasite life cycle. Our results may also be associated with the higher expression of the interleukin 10 (IL10) gene, which is generally observed in Eimeria-challenged chickens [51], as IL10 can inhibit the synthesis of cytokines including IL1 $\beta$, IL2, and TNF- $\alpha$ [55]. Sand et al. [56] suggested that the potentially inappropriate activation of IL10 is a defense strategy used by Eimeria spp. to escape immune detection in the intestinal tract of the host. Interferon gamma plays a critical role in mediating protective immunity against coccidiosis [57]. EC chickens had higher IFNG expression than UC chickens, a finding that can be explained by the importance of this cytokine as a mediator of resistance to
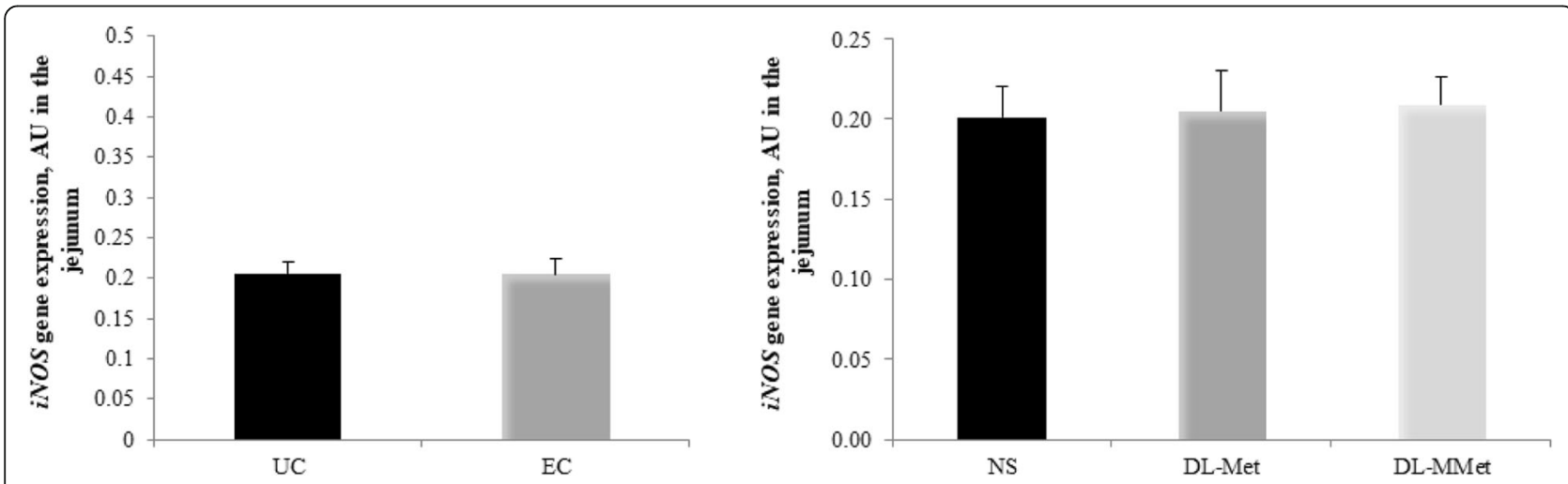

Fig. 9 Effect of Eimeria spp. challenge and methionine supplementation on the expression of inducible nitric oxide synthase gene, iNOS in the jejunum of broilers $144 \mathrm{~h}$ post-inoculation. Results are expressed as arbitrary units, AU, and are presented as mean and standard error. UC = unchallenged broilers; EC = Eimeria-challenged broilers. NS = non-supplemented diet; DL-Met = diet supplemented with free methionine; DL-MMet = diet supplemented with methionine dipeptide 
protozoans, including those of the genus Eimeria [51]. Studies demonstrated that interferon gamma levels increase during coccidiosis and that this molecule plays a particular role in the activation of intracellular toxicity via free radical generation and decreasing oocyst production during primary infection with Eimeria spp. [57, 58]. However, the inflammatory process in the intestine of a parasitized animal is accompanied by damages to the intestinal epithelium and tight junctions (TJs). Claudins and occludin are dynamic TJ proteins that function as a selective/semipermeable barrier that facilitates the transport of ions and solutes through the paracellular space while preventing the passage of luminal antigens, microorganisms, and toxins [59]. Chickens with coccidiosis have lower occludin gene expression levels as a consequence of multiple factors, including inflammation [60]. We suggest the low OCLN expression observed in this study might be due to the immune responses triggered by interferon gamma [61]. Low occludin levels are associated with the disruption of TJs in the jejunum and consequently with the passive loss of solutes and the osmotically driven flow of water into the intestine, resulting in diarrhea, one of the main signs of intestinal inflammation [60].

Interferon gamma also affects the intracellular replication of Eimeria spp. [57] because it is a potent activator of inducible nitric oxide synthase (iNOS), an enzyme responsible for the production of nitric oxide (NO), which in turn has been proposed to be the effector molecule against Eimeria spp. [62]. NO is a highly reactive free radical synthesized from L-arginine by nitric oxide synthases (NOS) [63, 64]. This free radical performs a variety of biological functions [65] and acts as a cytotoxic agent against tumor cells, bacteria, viruses, and parasites [64]. Because of its oxidizing effect and ability to react with intracellular compounds, $\mathrm{NO}$ is generated in large quantities during immunological reactions [66].

In this study, we quantified the nitrite content in the jejunum of EC and UC chickens and evaluated both iNOS and CAT-1 expression. The CAT-1 gene codes for CAT-1, a protein involved in the absorption of arginine, which is the substrate for NO synthesis. Eimeria spp. infection had no effect on $i N O S$ expression but increased CAT-1 expression and nitrite content. The lack of significant results for $i N O S$ expression can be due to the time of sampling (144 h PI). Once expressed, iNOS produces high levels of NO for periods that can last from hours to days [63]. Overall, these results suggest that a highly complex and integrated intestinal defense mechanism is activated in an attempt to fight the coccidial infection via increased expression of IFNG and CAT-1 and, consequently, enhanced production of $\mathrm{NO}_{2}{ }^{-}$, which is toxic for coccidians [62].

Studies evidenced the occurrence of oxidative stress in chickens challenged with Eimeria spp. [2, 9, 10]. Oxidative imbalance in chickens with coccidiosis is caused by reduced antioxidant enzyme activity; reduced levels of non-enzymatic antioxidants, such as carotenoids, vitamin $\mathrm{C}$, and vitamin $\mathrm{E}$; increased lipid peroxidation; and increased $\mathrm{NO}_{2}{ }^{-}$and nitrate $\left(\mathrm{NO}_{3}{ }^{-}\right)$levels $[2,9-11]$. In the present study, we found that EC chickens $144 \mathrm{~h}$ PI had higher TBARS and nitrite contents in the jejunum than UC chickens. These alterations may be due to the effects of $\mathrm{NO}$ and oxygen-derived radicals, which produce other toxic substances, such as the potent oxidizing agent peroxynitrite [67], and result in lipid peroxidation. Oxidative stress also causes damage to others biological molecules. Proteins are possibly the most immediate vehicle for inflicting oxidative damage on cells because they usually act as catalysts rather than as stoichiometric mediators [68]. Reactions between proteins and free radicals can lead to the formation of protein derivatives or peptide fragments that possess highly reactive carbonyl groups. In fact, the accumulation of carbonylated proteins has been observed in several diseases, including intestinal diseases [69, 70]. EC chickens fed the NS diet showed high carbonylated protein content, indicating that peroxynitrite formation might have occurred during the infection, causing severe oxidative damage to proteins. Moreover, this result shows that methionine deficiency enhances oxidative stress in the jejunum and is evidence of the importance of the amino acid for broiler health. Methionine residues have been shown to be potent endogenous antioxidants that regulate the activity of biological proteins [15]. In addition to the direct antioxidant effect of methionine residues in proteins, the organism has a highly sophisticated enzyme system that minimizes the deleterious effects of oxidation. SOD and CAT are examples of important antioxidant enzymes.

In our study, the lowest expression levels of SOD1 and $C A T$ were observed in EC chickens. EC broilers fed the NS diet had lower CAT activity but higher SOD activity than EC broilers fed the $D L$-Met or DL-MMet diets. The reduction in CAT expression and consequently in CAT activity might have been caused by $\mathrm{NO}$ production and as a result of cellular damage in the jejunum [71, 72], which allows us to infer that the formation of toxic substances during the coccidial infection exceeded the antioxidant capacity of the defense system. This condition might have been further aggravated by methionine deficiency and by the fact that NO can inhibit the enzyme glutathione peroxidase [73]. On the other hand, higher SOD activity seems to be useful to combat the excess free radicals produced during the infection, resulting in a lower expression of the SOD1 gene. Another possible explanation for the high SOD activity observed is the existence of cellular compensatory responses to the deficiency of methionine and other non-enzymatic antioxidants observed during the infection [11, 74]. Therefore, methionine deficiency and the inactivation of 
CAT can at least partially explain the lipid and protein oxidation observed in the jejunum of EC broilers fed the NS diet. Another interesting result of this study is that chickens fed the $D L$-Met and $D L$-MMet diets had lower nitrite content, which may be associated with the ability of methionine to react with RNS, thereby preventing cellular oxidation. This result highlights the importance of methionine, both as free amino acid and dipeptide, for the maintenance of intestinal epithelium. Furthermore, we observed that EC chickens fed the DL-MMet diet exhibited higher TAC, as did UC chickens fed the DL-Met and $D L$-MMet diets. These unprecedented results indicate that methionine dipeptide supplementation might play a key role in protecting the intestinal environment against oxidative stress in broilers challenged with Eimeria spp.

\section{Conclusions}

We concluded that the poor performance observed in chickens challenged with Eimeria spp. probably occurred as a consequence of inflammatory responses and oxidative stress in the jejunum, which in turn might have affected intestinal epithelial integrity. The main effect of methionine supplementation was on antioxidant metabolism. Our results showed for the first time that free methionine and methionine dipeptide supplementation is able to protect the intestinal cells of broilers under Eimeria challenge from the oxidative damage induced by free radicals.

\section{Abbreviations}

ACTB: Beta actin gene; ANOVA: Analysis of variance; $B^{0}$ AT1: Neutral amino acid transporter 1 gene; BWG: Body weight gain; CAT-1: Cationic amino acid transporter 1 gene; CAT: Catalase; CAT: Catalase gene; cDNA: Complementary DNA; CLDN1: Claudin-1 gene; CP: Carbonylated protein; DL-Met: free $D L-$ methionine; DL-MMet: DL-methionyl-DL-methionine; DNA: Deoxyribonucleic acid; DNPH: 2,4-dinitrophenylhydrazine; DPPH: 2,2-diphenyl-1-picrylhydrazyl; EC: Eimeria-challenged; EDTA: Ethylenediaminetetraacetic acid; FCR: Feed conversion ratio; Fl: Feed intake; $\mathrm{H}_{2} \mathrm{O}_{2}$ : Hydrogen peroxide; $\mathrm{HCl}$ : Hydrochloric acid; IFNG: Interferon gamma gene; IL-10: Interleukin 10; IL1B: interleukin 1 beta gene; IL2: Interleukin 2 gene; iNOS: Inducible nitric oxide synthase gene; LITAF: Lipopolysaccharide-induced tumor necrosis factor (TNF)-alpha factor gene; MHA: Methionine hydroxy analog; MyD88: Myeloid differentiation primary response 88; $\mathrm{NaNO}_{2}$ : Sodium nitrite; $\mathrm{NCBI}$ : National Center for Biotechnology Information; NED: N-(1-naphthyl) ethylenediamine dihydrochloride; ng: Nanogram; nm: Nanometer; nmol: Nanomo; NO: Nitric oxide; $\mathrm{NO}_{2}-$ : Nitrite; $\mathrm{NO}_{3}{ }^{--}$: Nitrate; NOS: Nitric oxide synthases; NS: Nonsupplemented; $\mathrm{O}_{2}$ : Superoxide anion; OCLN: Occludin gene; PAMP: Pathogen-associated molecular patterns; PEPT1: Peptide transporter 1 gene; PI: Post-inoculation; RNA: Ribonucleic Acid; RNS: Reactive nitrogen species; ROS: Reactive oxygen species; RT-qPCR: Reverse transcription polymerase chain reaction quantitative real time; SOD: Superoxide dismutase; SOD1: Superoxide dismutase 1 gene; spp.: Species; TAC: Total antioxidant capacity; TBARS: Thiobarbituric acid reactive substances; TJ: Tight junctions; TLR: Toll-like receptor; TLR2: Toll-like receptor 2 gene; TLR5: Toll-like receptor 5 gene; TNF: Tumor necrosis factor; TRIF: TIR-domain-containing adapterinducing interferon- $\beta$; U: Unit; UC: unchallenged; $y^{+}$LAT-1: Neutral and cationic amino acid transporter 1 gene

\section{Acknowledgements}

The authors would like to thank the Department of Animal Science and the Postgraduate Program in Animal Science of the Maringá State University for technical support.

\section{Funding}

This research was funded by the National Council of Technological and Scientific Development (CNPq), Brazil (Project no. 445322/2014-4).

\section{Availability of data and materials}

The datasets used and/or analysed during the current study are available from the corresponding author on reasonable request.

\section{Authors' contributions}

EG conceived and designed the experiment. EG, ASK, APDV, ARON and RPMF performed the research. ASK, ARON, and EG conducted the experiment. ASK, APDV, ARON and EG collected the samples and data. ASK, APDV and RPMF carried out the biochemical and molecular. EG and ASK performed the statistical analysis. ASK, APDV and EG wrote the manuscript. All authors performed experiments, read and approved the final manuscript.

\section{Ethics approval and consent to participate}

This study was approved by the animal experiment was approved by the Ethics Committee on Animal Use ( $n^{\circ}$ 4000170615) of the State University of Maringá (Maringá, Paraná, Brazil).

\section{Consent for publication}

Not applicable.

\section{Competing interests}

The authors declare that they have no competing interests.

\section{Author details}

${ }^{1}$ Animal Science Department, State University of Maringá, Colombo Avenue, 5790, Jardim Universitário, Maringá, Paraná 87020-900, Brazil. ${ }^{2}$ Animal Science Department, Federal University of Sergipe, Marechal Rondon Avenue, S/N, Jardim Rosa Elze, São Cristóvão, Sergipe 49100-000, Brazil. 'EVONIK of Brazil, Arquiteto Olavo Redig de Campos Street, 105, Tower A, São Paulo, SP 04711-904, Brazil. "Physiology Departament, Federal University of Sergipe, Marechal Rondon Avenue, S/N, Jardim Rosa Elze, São Cristóvão, Sergipe 49100-000, Brazil.

Received: 10 December 2018 Accepted: 12 April 2019

Published online: 27 June 2019

\section{References}

1. Lillehoj HS, Trout JM. Avian gut-associated lymphoid tissues and intestinal immune responses to Eimeria parasites. Clin Microbiol Rev. 1996;9:349-60.

2. Bun SD, Guo YM, Guo FC, Ji FJ, Cao H. Influence of organic zinc supplementation on the antioxidant status and immune responses of broilers challenged with Eimeria tenella. Poult Sci. 2011;90:1220-6.

3. Major JR Jr, Ruff MD. Disaccharidase activity in the intestinal tissue of broilers infected with coccidia. J Parasitol. 1978;64:706-11.

4. Adams C, Vahl HA, Veldman A. Interaction between nutrition and Eimeria acervulina infection in broiler chickens: development of an experimental infection model. Br J Nutr. 1996;75:867-73.

5. Su S, Miska KB, Fetterer RH, Jenkins MC, Wong EA. Expression of digestive enzymes and nutrient transporters in Eimeria-challenged broilers. Exp Parasitol. 2015;150:13-21.

6. Morris BC, Danforth HD, Caldwell DJ, Pierson FW, McElroy AP. Intestinal mucosal mast cell immune response and pathogenesis of two Eimeria acervulina isolates in broiler chickens. Poult Sci. 2004;83:1667-74.

7. Gottardo ET, Prokoski K, Horn D, Viott AD, Santos TC, Fernandes J. Regeneration of the intestinal mucosa in Eimeria and E. Coli challenged broilers supplemented with amino acids. Poult Sci. 2016;95:1056-65.

8. Miska KB, Fetterer $\mathrm{RH}$. The effect of Eimeria maxima infection on the expression of amino acid and sugar transporters aminopeptidase, as well as the di- and tri-peptide transporter PepT1, is not solely due to decreased feed intake. Poult Sci. 2018;97:1712-21.

9. Allen PC. Production of free radical species during Eimeria maxima infections in chickens. Poult Sci. 1997;76:814-21.

10. Georgieva NV, Koinarski V, Gadjeva V. Antioxidant status during the course of Eimeria tenella infection in broiler chickens. Vet J. 2006;172:488-92.

11. Allen PC, Fetterer $\mathrm{RH}$. Interaction of dietary vitamin E with Eimeria maxima infections in chickens. Poult Sci. 2002:8:41-8. 
12. Lillehoj HS, Min W, Dalloul RA. Recent progress on the cytokine regulation of intestinal immune responses to Eimeria. Poult Sci. 2004;83:611-23.

13. Quiroz-Castañeda RE, Dantán-González E. Control of avian coccidiosis: future and present natural alternatives. Biomed Res Int. 2015;2015:1-11.

14. Swain BK, Johri TS. Effect of supplemental methionine, choline and their combinations on the performance and immune response of broilers. $\mathrm{Br}$ Poult Sci. 2000;41:83-8.

15. Levine RL, Mosoni L, Berlett BS, Stadtman ER. Methionine residues as endogenous antioxidants in proteins. Proc Natl Acad Sci U S A. 1996;93: $15036-40$.

16. Mamauag REP, Gao J, Nguyen BT, Ragaza JA. Supplementations of DLmethionine and methionine dipeptide in diets are effective for the development and growth of larvae and juvenile Red Sea bream, Pagrus major. J World Aquac Soc. 2012;43:362-74.

17. Chen Q, Dai W, Sun Y, Zhao F, Liu J, Liu H. Methionine partially replaced by methionyl-methionine dipeptide improves reproductive performance over methionine alone in methionine-deficient mice. Nutrients. 2018;10:1-14.

18. Gillbert ER, Wong EA, Webb KE Jr. Board-invited review: peptide absorption and utilization: implications for animal nutrition and health. J Anim Sci. 2008:86:2135-55.

19. Dabrowski K, Lee KJ, Rinchard J. The smallest vertebrate, teleost fish, can utilize synthetic dipeptide-based diets. J Nutri. 2003;133:4225-9.

20. Daniel H. Molecular and integrative physiology of intestinal peptide transport. Annu Rev Physiol. 2004;66:361-84

21. Matthews DM, Adibi SA. Peptide absorption. Gastroenterology. 1976;71:151-61.

22. Barbot L, Windsor E, Rome S, Tricottet V, Reynès M, Topouchian A, Huneau JF, Gobert JG, Tomé D, Kapel N. Intestinal peptide transporter PepT1 is overexpressed during acute cryptosporidiosis in suckling rats as a result of both malnutrition and experimental parasite infection. Parasitol Res. 2003:89:364-70.

23. Del Vesco AP, Gasparino E, Grieser DO, Zancanela V, Soares MA, Neto ARO. Effects of methionine supplementation on the expression of oxidative stress-related genes in acute heat stress-exposed broilers. $\mathrm{Br} J$ Nutr. 2015;113:549-59.

24. Gasparino E, Del Vesco AP, Khatlab AS, Zancanela V, Grieser DO, Silva SCC. Effects of methionine hydroxy analogue supplementation on the expression of antioxidant-related genes of acute heat stress-exposed broilers. Animal. 2018;12:931-9.

25. Rostagno HS, Albino LFT, Donzele JL, Gomes PC, Oliveira RF, Lopes DC, Ferreira AS, Barreto SLT, Euclides RF. Brazilian tables for poultry and swine: composition of feedstuffs and nutritional requirements, 3rd ed. Viçosa: UFV; 2011.

26. Gordon $\mathrm{H}$, Whitlock AV. A new technique for counting nematode eggs in sheep feces. J Council Sci Industry Res. 1939;12:50-2.

27. Aebi H. Catalase in vitro. Methods Enzymol. 1984;105:121-6.

28. Marklund S, Marklund G. Involvement of the superoxide anion radical in the autoxidation of pyrogallol and a convenient assay for superoxide dismutase. Eur J Biochem. 1974:47:469-74.

29. Watanabe N, Miura S, Zeki S, Ishii H. Hepatocellular oxidative DNA injury induced by macrophage-derived nitric oxide. Free Radic Biol Med. 2001;30: 1019-28.

30. Griess P. Comments on the treatise of the HH. Weselsky and Benedikt "about some azo compounds". Ber German Chem Ges. 1879;12:426-8.

31. Buege JA, Aust SD. Microsomal lipid peroxidation. Methods Enzymol. 1978; 52:302-10.

32. Levine RL, Williams JA, Stadtman ER, Shacter E. Carbonyl assays for determination of oxidatively modified proteins. Methods Enzymol. 1994;233: 346-57.

33. Brand-Wiliams W, Cuvelier ME, Berset C. Use of a free radical method to evaluate antioxidant activity. LWT-Food Sci Technol. 1995;28:25-30.

34. Bradford MM. A rapid and sensitive method for the quantitation of microgram quantities of protein utilizing the principle of protein-dye binding. Anal Biochem. 1976;72:248-54.

35. Livak KJ, Schmittgen TD. Analysis of relative gene expression data using real-time quantitative PCR and the $2^{-\Delta \Delta C T}$ method. Methods. 2001;25:402-8.

36. McDermott JR, Leslie FC, D'Amato M, Thompson DG, Grencis RK, McLaughlin JT. Immune control of food intake: enteroendocrine cells are regulated by $\mathrm{CD}^{+} \mathrm{T}$ lymphocytes during small intestinal inflammation. Gut. 2006;55:492-7.

37. Chen H, Pan Y, Wong EA, Webb KE Jr. Dietary protein level and stage of development affect expression of an intestinal peptide transporter (cPepT1) in chickens. J Nutr. 2005;135:193-8.
38. Silva V, Mencalha R, Arruda N, Alcebíades S, Bertechini A. Bioefficacy of different sources of methionine relative to DL-methionine in starter phase (1 to 21 days) of broilers chickens. Poult Sci. 2016;95:144 (Abstr.).

39. Fetterer RH, Allen PC. Eimeria tenella infection in chickens: effect on plasma and muscle 3-methylhistidine. Poult Sci. 2001;80:1549-53.

40. Heckert RA, Estevez I, Russek-Cohen E, Pettit-Riley R. Effects of density and perch availability on the immune status of broilers. Poult Sci. 2002;81:451-7.

41. Akhtar M, Awais MM, Anwar MI, Ehtisham-ul-Haque S, Nasir A, Saleemi MK, Ashraf K. The effect of infection with mixed Eimeria species on hematology and immune responses following Newcastle disease and infectious bursal disease booster vaccination in broilers. Vet Q. 2015:35:21-6.

42. Panda B, Combs GF. Effect of coccidiosis on different glands of the growing chick. Avian Dis. 1964;8:7-12

43. Bozkurt M, Aysul N, Küçükyilmaz K, Aypak S, Ege G, Catli AU, Aksit $H$, Cöven F, Seyrek K, Cinar M. Efficacy of in-feed preparations of an anticoccidial, multienzyme, prebiotic, probiotic, and herbal essential oil mixture in healthy and Eimeria spp.-infected broilers. Poult Sci. 2014;93: $389-99$.

44. Nakamura K, Imada Y, Maeda M. Lymphocytic depletion of bursa of Fabricius and thymus in chickens inoculated with Escherichia coli. Vet Pathol. 1986:23:712-7.

45. Sun L, Dong H, Zhang Z, Liu J, Hu Y, Ni Y, Grossmann R, Zhao R. Activation of epithelial proliferation induced by Eimeria acervulina infection in the duodenum may be associated with cholesterol metabolism. Oncotarget. 2016;7:27627-40.

46. Gazzinelli RT, Denkers EY. Protozoan encounters with toll-like receptor signalling pathways: implications for host parasitism. Nat Rev Immunol. 2006;6:895-906.

47. Z-y Z, S-j H, Z-y W, Z-I G, Qin B, Nie K. Expression of chicken toll-like receptors and signal adaptors in spleen and cecum of young chickens infected with Eimeria tenella. J Integr Agric. 2014;13:904-10.

48. Iqbal M, Philbin VJ, Smith AL. Expression patterns of chicken toll-like receptor mRNA in tissues, immune cell subsets and cell lines. Vet Immunol Immunopathol. 2005;104:117-27.

49. Feng $\mathrm{T}$, Cong $\mathrm{Y}$, Alexander $\mathrm{K}$, Elson CO. Regulation of toll-like receptor 5 gene expression and function on mucosal dendritic cells. PLoS One. 2012:7:e35918.

50. Zhang L, Liu R, Ma L, Wang Y, Pan B, Cai J, Wang M. Eimeria tenella: expression profiling of toll-like receptors and associated cytokines in the cecum of infected day-old and three-week old SPF chickens. Exp Parasitol. 2012;130:442-8

51. Hong YH, Lillehoj HS, Lee SH, Dalloul RA, Lillehoj EP. Analysis of chicken cytokine and chemokine gene expression following Eimeria acervulina and Eimeria tenella infections. Vet Immunol Immunopathol. 2006;114:209-23.

52. Netea MG, van der Graaf C, Van der Meer JW, Kullberg BJ. Toll-like receptors and the host defense against microbial pathogens: bringing specificity to the innate-immune system. J Leukoc Biol. 2004;75:749-55.

53. Tang L, Wang G-X, Jiang J, Feng L, Yang L, Li S-H, Kuang S-Y, Zhou X-Q. Effect of methionine on intestinal enzymes activities, microflora and humoral immune of juvenile Jian carp (cyprinus carpio var. Jian). Aquac Nutr. 2009;15:477-83

54. Kaiser P, Rothwell L, Galyov EE, Barrow PA, Burnside J, Wigley P. Differential cytokine expression in avian cells in response to invasion by Salmonella typhimurium, Salmonella enteritidis and Salmonella gallinarum. Microbiology. 2000;146:3217-26.

55. Arendt MK, Sand JM, Marcone TM, Cook ME. Interleukin-10 neutralizing antibody for detection of intestinal luminal levels and as a dietary additive in Eimeria challenged broiler chicks. Poult Sci. 2016;95:430-8.

56. Sand JM, Arendt MK, Repasy A, Deniz G, Cook ME. Oral antibody to interleukin-10 reduces growth rate depression due to Eimeria spp. infection in broiler chickens. Poult Sci. 2016;95:439-46.

57. Lillehoj HS, Choi KD. Recombinant chicken interferon-gamma-mediated inhibition of Eimeria tenella development in vitro and reduction of oocyst production and body weight loss following Eimeria acervulina challenge infection. Avian Dis. 1998:42:307-14.

58. Dkhil M, Abdel-Baki AA, Delić D, Wunderlich F, Sies H, Al-Quraishy S. Eimeria papillata: upregulation of specific miRNA-species in the mouse jejunum. Exp Parasitol. 2011;127:581-6.

59. Groschwitz KR, Hogan SP. Intestinal barrier function: molecular regulation and disease pathogenesis. J Allergy Clin Immunol. 2009;124:3-20.

60. John LJ, Fromm M, Schulzke JD. Epithelial barriers in intestinal inflammation. Antioxid Redox Signal. 2011;15:1255-70. 
61. Mankertz J, Tavalali S, Schmitz H, Mankertz A, Riecken EO, Fromm M, Schulzke JD. Expression from the human occludin promoter is affected by tumor necrosis factor alpha and interferon gamma. J Cell Sci. 2000; 113:2085-90

62. Ovington KS, Smith NC. Cytokines, free radicals and resistance to Eimeria. Parasitol Today. 1992;8:422-6.

63. Kröncke KD, Fehsel K, Kolb-Bachofen V. Inducible nitric oxide synthase in human diseases. Clin Exp Immunol. 1998;113:147-56.

64. MacMicking J, Xie QW, Nathan C. Nitric oxide and macrophage function. Annu Rev Immunol. 1997;15:323-50.

65. Bredt DS. Endogenous nitric oxide synthesis: biological functions and pathophysiology. Free Radic Res. 1999;31:577-96.

66. James SL. Role of nitric oxide in parasitic infections. Microbiol Rev. 1995;59: 533-47.

67. Beckman JS, Beckman TW, Chen J, Marshall PA, Freeman BA. Apparent hydroxyl radical production by peroxynitrite: implications for endothelial injury from nitric oxide and superoxide. Proc Natl Acad Sci U S A. 1990; 87:1620-4.

68. Galicia-Moreno M, Rosique-Oramas D, Medina-Avila Z, Álvarez-Torres T, Falcón D, Higuera-de la Tijera F, Béjar YL, Cordero-Pérez P, Muñoz-Espinosa L, Pérez-Hernández JL, David Kershenobich D, Gutierrez-Reyes G. Behavior of oxidative stress markers in alcoholic liver cirrhosis patients. Oxidative Med Cell Longev. 2016;2016:1-10

69. Keshavarzian A, Banan A, Farhadi A, Komanduri S, Mutlu E, Zhang Y, Fields JZ. Increases in free radicals and cytoskeletal protein oxidation and nitration in the colon of patients with inflammatory bowel disease. Gut 2003:52:720-8.

70. Stadtman ER, Levine RL. Free radical-mediated oxidation of free amino acids and amino acid residues in proteins. Amino Acids. 2003;25:207-18.

71. Brown GC. Reversible binding and inhibition of catalase by nitric oxide. Eur J Biochem. 1995;232:188-91.

72. Cam Y, Atasever A, Eraslan G, Kibar M, Atalay O, Beyaz L, Inci A, Liman BC. Eimeria stiedae: experimental infection in rabbits and the effect of treatment with toltrazuril and ivermectin. Exp Parasitol. 2008:119:164-72.

73. Asahi M, Fujii J, Suzuki K, Seo HG, Kuzuya T, Hori M, Tada M, Fujii S, Taniguchi N. Inactivation of glutathione peroxidase by nitric oxide. Implication for cytotoxicity. J Biol Chem. 1995;270:21035-9.

74. Ruff MD, Witlock DR, Smith RR. Eimeria acervulina and E. tenella: effect on methionine absorption by the avian intestine. Exp Parasitol. 1976;39:244-51.

Ready to submit your research? Choose BMC and benefit from:

- fast, convenient online submission

- thorough peer review by experienced researchers in your field

- rapid publication on acceptance

- support for research data, including large and complex data types

- gold Open Access which fosters wider collaboration and increased citations

- maximum visibility for your research: over $100 \mathrm{M}$ website views per year

At $\mathrm{BMC}$, research is always in progress.

Learn more biomedcentral.com/submissions 